\title{
PERSONALITY TRAITS AND STRESS AS PREDICTORS OF PSYCHOLOGICAL WELL-BEING AMONG STUDENTS IN SCHOOLS OF NURSING AND MIDWIFERY MAKURDI
}

\author{
${ }^{1}$ Dzer, Benjamin Terzungwe, $\mathrm{PhD} ;{ }^{2}$ Atsehe, Josephine Iveren $\&^{3}$ Tomen, Egbe Agu, PhD \\ ${ }^{1}$ Department of Nursing, College of Health Sciences, Benue State University, Makurdi. \\ ${ }^{2}$ Federal Neuro-Psychiatric Hospital, Maiduguri, Borno State. \\ ${ }^{3}$ Department of Public Health, Taraba State University, Jalingo. \\ ${ }^{1}$ Email:bendzer86@gmail.com phone No: +234 (0) 8036146069
}

\begin{abstract}
This study investigated personality traits and stress as predictors of psychological well-being among students in schools of nursing and midwifery, Makurdi. The study employed the ex post facto research design. The Big Five Personality traits Scale, Perceived Stress Scale, and Ryff's Scale of psychological well-being were used to collect data from the participants. The participants constituted 25 (10.2\%) males and 220 (89.8\%) females with a mean age of 0.992. The study tested three hypotheses and each of the hypotheses tested six dimensions of Ryff's psychological well-being using simple linear regression and multiple linear regressions. Result in hypothesis (1a) showed a significant outcome for conscientiousness, openness and neuroticism on psychological well-being (autonomy) $[F(5,239)=181.093, P<.001$. Hypothesis $(1 \mathrm{~b})$ likewise had a significant outcome for conscientiousness, openness and neuroticism on psychological well-being (environmental mastery) $[F(5,329)=44.720, P<.001$. Hypothesis $(1 c)$ was accepted for conscientiousness, neuroticism and openness on psychological well-being (personal growth) $[F(5,237)=71.964, P<.001$. Hypothesis $(1 d)$ was confirmed for conscientiousness, neuroticism and openness on psychological well-being (positive relations with others) $[F(5,239)$ $=77.131, P<.001$. Hypothesis (1e) was accepted for all except extraversion on psychological well-being (purpose in life) $[F(5,239)=53.709, P<.001$. Hypothesis $(1 f)$ was confirmed only for openness on psychological well-being (self-acceptance) $[F(2,237)=28.625 P<.001$. Hypotheses (2a) to (2f) rejected the postulation of stress on all the dimensions of psychological well-being. Likewise, hypotheses ( $3 a)$ to $(3 f)$ also rejected the joint predictions of personality traits and stress on psychological well-being among students. In conclusion, Personality traits significantly predicted psychological well-being of students in schools of nursing and midwifery, Makurdi. Particularly, conscientiousness, neuroticism and openness personality traits found to influence psychological well-being while extraversion and agreeableness were the lowest personality traits influencing psychological well-being among students. In the contrary, stress rather positively predicted student's psychological well-being as against earlier postulation that stress will negatively and significantly influence psychological well-being among students. Based on the findings, that personality traits and stress did not jointly influence psychological wellbeing among students in schools of nursing and midwifery, Makurdi. It was recommended that, more empirical research be geared towards student nurses'/midwives' psychological well-being owning to their different personality traits in the course of their professional program. More so, research should be focused on Ryff's dimensions of psychological well-being since psychological well-being is not a single construct but multidimensional to assist student nurses/midwives gain optimal psychological well-being.
\end{abstract}

Keywords: Personality Traits, Stress, Psychological Well-being. 


\section{Introduction}

Optimal Performance in clinical areas such as hospitals and academic life demands all aspects of well-being, those that include physical, social, emotional, spiritual, and psychological well-being (Crystal, Chen, Fuligni, Stevenson, Hsu, Ko, Kitamura, \& Kimura, 2014). Students with high levels of well-being are considered to be more productive and are more likely to add value to their communities. Psychological well-being is indeed an important predictor that could contribute to high performance in clinical areas and academic achievement of students. Hence, it is very crucial to review and examine the psychological well-being of the students to helping them obtain optimal psychological well-being and examine the variables that may hinder optimal psychological well-being.

Psychological well-being is a dynamic concept that includes subjective, social, and psychological dimensions as well as health-related behaviors. Carol Ryff's model of Psychological Well-being differs from past models in one important way: psychological wellbeing is multidimensional, and not merely about happiness, or positive emotions. A good life is balanced and whole, engaging each of the different aspects of psychological well-being, instead of being narrowly focused. Ryff roots this principle in Aristotle's Nichomachean Ethics, where the goal of life isn't feeling good, but is instead about living virtuously.

Students in Nursing and Midwifery Schools, who are undergoing studies to become professional Nurses under the Nursing and Midwifery Council of Nigeria (NMCN), are faced with numerous challenges ranging from stress, depression, anxiety, clinical practice training, personal life challenges, academic workload, inadequate time for leisure, and time for holidays among others.

On observing this group of students for a period of five years as a tutor in the School, the researcher gained insight that, for students in Schools of Nursing and Midwifery to perform optimally in their career upon graduation and produce level in empathy, their psychological well-being needs to be optimally stable.

However, couple with different personality of students Nurses, who face these challenges, others may see it as normal while others may see it as stressful and demanding.

Ryff (2006) has conceptualized psychological well-being as consisting of 6 dimensions: autonomy, environmental mastery, personal growth, positive relations with others, purpose in life, self-acceptance. She has designed self-report scales to assess individual's well-being at a particular moment in time within each of these 6 dimensions. Three- to 12- items per scale validated versions exist of the measure for use in survey research or other data collection. Individuals respond to various statements and indicate on a 6-point Likert scale how true each statement is of them. Higher scores on each scale indicate greater well-being on that dimension.

According to psychological well-being theory, individual's psychological well-being depends on his positive functioning in certain aspects of his life. Individual should have in positive relationship with others; should be dominant over the environment; should accept himself and his past; should have a goal and meaning in his life; should have personal development and the ability to make his own decisions (Özen, 2012). Extensive analysis of psychological well- 
being includes individual's relationship with life goals; if he is aware of his potential; the quality of his relationship with others; and what he feels about his own life (Ryff and Keyes, 1995).

Schools of nursing and midwifery environment appear to have both positive and negative impact on psychological well-being of students as right from day one of their admission to their last days in writing their professional council examinations.

Students who are physically and who have optimal psychologically well-being are expected to perform better compared to those who are not physically, mentally and psychologically fit. In other words, those who are experiencing psychological problems, such as stress, depression in relation with personality traits, may face problems in managing their psychological well-being thereby not excelling in their academic performance. Psychological well-being is indeed an important predictor that could contribute to psychological well-being and enhance professionalism. Hence, it is very much crucial to review and examine the psychological well-being of the students.

Psychological well-being is a vital part of students' overall well-being with students nurses not an exception. A student in positive well-being is more likely to effectively meet life's demands, including those associated with nursing education (Kucirka, 2013; Hawker, 2012).

Nursing education is a long process where students face multiple psychological well-being issues such as anxiety, depression, stress and so many health challenges as a result of academic overload, lack of leisure time, emotional pressure to maintain good grades, examinations, assignments, academic competition and performance evaluations in clinical settings while working concurrently with patients.

Many variables may be associated with psychological well-being. Among such factors are; personality traits, stress, depression, anxiety, demographic factors etc .However, the present study focus on examining how personality traits and stress may influence psychological wellbeing of students in schools of nursing and midwifery Makurdi.

Personality is that which makes us what we are and it makes us different from others. It is seen as a complex pattern of deeply embedded psychological characteristics that are expressed automatically in almost every area of psychological functioning. In the words of Ryckman (2004), personality is defined as a dynamic and organized set of characteristics possessed by a person that uniquely influences his or her cognitions, motivations and behaviors in various situations.

There are various models of personality such as biological, psycho-dynamic, interpersonal, cognitive, trait and factorial perspectives. Among which, the five factor model is the most prominent current model of personality which was derived from the analyses of various personality inventories, (Costa and McCrae, 1992). It postulates five largely independent and relatively broadly designed personality dimensions such as, Neuroticism (the tendency to exhibit poor emotional adjustment such as anxiety, impulsivity and fear), Extraversion (the tendency to be active, sociable, assertive and directive), Openness to Experience (the tendency to be creative, autonomous and curious), Agreeableness (the 
tendency to be cheerful, likeable and cooperative) and Conscientiousness (the tendency to have a sense of achievement and dependability). Some researchers had observed that these five traits cover the broad domain of personality to a large extent and provide a good perspective for the description of personality.

Among the different models of personality, the Big Five Model is extensively researched with students (Rubinstein, 2005; Bidjeranoet al., 2007 \& White et al., 2009), and will be use in this context of research.

For instance McCrae and Costa (1992) indicated that neuroticism which they said relates to a tendency to experience dysphoric affect, sadness, hopelessness and guilt was linked to low self esteem, irrational beliefs and pessimistic attitude. Extraversion, however, which they said was related to a preference to companionship and social stimulation, was linked to social skills e.g. having many friends. Also, openness to experience which has to do with the need for variety, novelty and change was linked to having interest in travels, different hobbies and diverse vocational interests.

Agreeableness which has to do with willingness to defer to others during interpersonal conflicts was linked to having forgiving attitudes, beliefs in cooperation and having inoffensive language.

With regards to conscientiousness the researchers posited that this has to do with strong sense of purpose and high aspiration level and they linked it to having leadership skills, long term plans, organized support network and technical expertise.

It has been argued that our thinking, feelings and behavior as well as our unique individuality contribute a lot to our psychological well-being and that based on personality traits some people may be more prone to mental psychological problems than others.

Besides personality traits, another factor that is purported to moderate psychological wellbeing among students in schools of nursing and midwifery is stress.

Stress is the emotional and physical strain caused by our response to pressure from the outside world. Stress from a psychosocial perspective, results from one's perception of imbalance between one's demands and resources, or from pressure that exceeds one's perceived ability to cope (Lazarus \&Folkman, 1984). Persistent stress that is not resolved through coping or adaptation leads to distress, which may translate into anxiety, pain, physical suffering, and withdrawal (Selye, 1975). It's almost impossible to live without some stress and most of us wouldn't want to, because it gives life some spice and excitement. But if stress gets out of control, it may harm health, your relationship and your enjoyment of life. Common stress reactions include tension, irritability, inability to concentrate and a variety of physical symptoms i.e. headache and fast heartbeat.

Stress can influence personal and social life and individual's psychological wellbeing. The importance of this issue is due to the fact that if we have stressed people, they cannot properly carry out their responsibilities, and they would be weak in the face of different life pressures. In addition, they cannot move toward their own goal so seriously and will feel disappointment in face of any obstacle, and perceived stress is referred to as 
Journal DOI: www.doi.org/10.46654/ij.24889849

Article DOI: www.doi.org/10.46654/ij.24889849.e7572

individuals' overall interpretation and understanding of the impact of stressors. Different people have different perceptions and interpretations of different stressors. There are a variety of factors that can play effective roles in the creation of stress and individual interpretation of the stress (Zibaei et al., 2012).

A dramatic increase in student stress is an alarming trend in college student health nationwide, as nearly $80 \%$ of students report being moderately stressed or burned out (Larson, 2006; Misra et al, 2000;). Since stress is known to have detrimental effects on the physical and mental well-being of students (Hall et al., 2006; Larson, 2006; Andrews \& Wilding, 2004; Nonis et al., 1998; Shapiro et al., 1998; Cohen \& Herbert, 1996; Van Eck et al., 1996), intervention is needed by assessing stress in college students and determining its impact on psychological well-being in order to establish ways to decrease the risk and increase the positive level of psychological well-being.

The two common types of stress frequently mentioned in the literature is a negative form known as distress, which causes the body to react in a negative way and can eventually lead the body to breakdown (Le Fevre et al., 2006; Suedfeld, 1997). However the other is considered to be positive, known as eustress. This form results from challenges and motivators in daily life and tends to encourage optimal performance which leads to success and positive self-esteem (Le Fevre et al., 2006; Suedfeld, 1997).

Students are subjected to different kinds of stressors such as the pressure of academics with an obligation to succeed, an uncertain future and difficulties of integrating into the system. The students also face social, emotional, physical and family problems which may affect their learning ability and academic performance. In recent years there is growing appreciation of stressors involved in nursing training College students, they are prone to stress due to the transitional nature of college life. Too much stress can cause physical and mental health problems, reduce self-esteem and may affect students academic achievement.

Lazarus (1966) believes that stress is based on individual characteristics, interactions with the environment as well as the personal cognitive representations.

Stress is a normal part of everyday living (Canadian Mental Health Association (2013) and is neither negative nor positive. It is peoples' perceptions of stressors and their perceived ability to cope that makes stress a positive or negative experience. At the right level, stress can heighten motivation and increase chances of success (Gibbins, 2010; Freeburn\& Sinclair, 2009). Having said this, eustress, or positive stress, is less likely to predict positive psychological well-being or result in "mental lift" in comparison to stress that leads to mental distress (Gibbins, 2010). Research between eustress and students nurses psychological wellbeing is nearly nonexistent unlike negative stress (Gibbins, 2010). This is concerning, having an awareness of the factors that contribute to positive and negative perception of stress/stressors may give educators clues as to why some students excel under stressful conditions while others become overwhelmed.

To complicate matters, the perception of, and threshold at which stress goes from being motivating to overwhelming varies from person to person (Hoff, Hallisey\& Hoff, 2009). A greater awareness of these factors may be the key to educators being able to better support 
Journal DOI: www.doi.org/10.46654/ij.24889849

Article DOI: www.doi.org/10.46654/ii.24889849.e7572

students as they navigate the many challenges associated with nursing and midwifery education.

Negatively perceived stress is the main factor negatively affecting student psychological well-being and a major academic performance concern (McGuinness\& Ahern, 2009).

Stresses associated with nursing school students include caring for acutely ill patients, witnessing death, mentor-mentee relationships, and competency assessments (Timmins, Corroon, Byrne, and Mooney, 2011). Nursing and midwifery students may doubt their clinical competence and may experience interpersonal problems with patients and their families (Gibbins, Dempster, \&Moutray, 2010). High workload, relationships with staff, lack of supervisory support, emotional needs of patients and their families, shift work, decision making, constantly changing conditions, and juggling patient and personal health needs are all nursing and midwifery student concerns (Reeve et al., 2013).

Students in schools of nursing and midwifery may be asked to carry out treatments patients do not agree with, understand, or fear, or cause unintentional pain during necessary treatment or procedures. Patients and their families may show signs of anger, depression, helplessness, and fear all of which can be mentally distressing to a student. Student's nurses have the added burden of knowing their actions, or lack of action, could harm or distress others as in administering the wrong medication or failing to recognize of a sign or symptom. All of these may be perceived negatively leading to the possibility of psychological distress and overall psychological well-being decline. Keeping these considerations in view, the current study is under taken to identify if personality traits and stress may predict psychological well-being among students in schools of nursing and midwifery Makurdi.

\section{Statements of the problem}

The psychological well-being of Students in schools of Nursing and Midwifery is a very important component in the training and development of Nurses. As pre-nursing program place challenges on Students and affect their psychological well-being.

Entrance into Nursing and Midwifery program marks a time of significant change in the life a young adult. For many Student Nurses/Midwives, Nursing/Midwifery School environment is a place where perfectionists are made, a place to make new friends, enjoy social life and social activities, fun and enjoyment of freedom. But on getting to School environment their perception about Nursing/Midwifery program changed as they are greeted with the adjustment problems leading to varieties of stress such academic and clinical stresses. 
Nursing profession is stressful, and Student Nurses also have additional pressures and uncertainties in their academic activities. Stress from many sources has been reported time to time by student nurses.

Academic sources of stresses include examinations, long hours of study, assignments and grades, lack of free time, faculty response to student need and lack of timely feedback. (Kipping 2010, Howard 2011) and the timing of examinations has a particular impact on the psychological well-being of student nurses. Student nurses also experience longer hours of study and an associated lack of free time (Jones \& Johnston 2012, Mahat 2010, Lo 2012). Stress experienced by student nurses is experienced by students generally.

Clinical sources of stress include working with dying patients, interpersonal conflict with other nurses, insecurity about personal clinical competence, fear of failure, interpersonal problems with patients, work overload and concerns about Nursing care given to patients.

Stress can lead to poor psychological well-being and several psychological disorders. Therefore, it is important for educators to know the prevalence of psychological distress in line with individual personalities as it affects psychological well-being of students. Psychological disorders are projected to be among the top fourth leading causes of disability in the future. By 2020 as indicated by the World Health Organization (2003b) 12\% of global diseases (121 million people will suffer from depression, 70 million from alcoholism, 24 million from schizophrenia and 37 experiences dementia) which is nearly $15 \%$ of the population.

Counseling services is normally offered for psychological cases to tackle psychological distress. Maximizing, preventing and maintaining the health and psychological well-being should be priority for education providers, practitioners and students themselves instead of treating psychological distress when it is not timely identify.

Despite the available coping strategies, students still experience stress and low psychological well-being. Could this be as a result of sex difference in stress that could influences psychological well-being? Or age difference and socioeconomic status?

Therefore, this study on influence of personality traits and stress on psychological well-being among students in schools of Nursing and Midwifery, Makurdi will pave way in understanding and managing the phenomena under study.

\section{Purpose of the study}

The purpose of this research is to determine personality traits and stress on psychological well-being among students in Schools of Nursing and Midwifery, Makurdi. Specifically, the study will examine if:

1) Personality traits (openness, conscientiousness, extraversion, agreeableness, neuroticism) will predict (autonomy, environmental mastery, personal growth, 
positive relations with others, purpose in life, self acceptance) psychological wellbeing of students in schools of nursing and midwifery, Makurdi.

2) Stress can influence (autonomy, environmental mastery, personal growth, positive relations with others, purpose in life, self acceptance) psychological well-being of students in schools of nursing and midwifery, Makurdi.

3) Personality traits and stress can jointly affect psychological well-being of students in schools of nursing and midwifery, Makurdi.

\section{Research questions}

In order to achieve the goals of this study, the present research seeks to answer the following questions:

1) To what extent does personality traits (openness, conscientiousness, extraversion, agreeableness, neuroticism) predict (autonomy, environmental mastery, personal growth, positive relations with others, purpose in life, self acceptance) psychological well-being of students in schools of nursing and midwifery, Makurdi?

2) What is the extent that stress influence (autonomy, environmental mastery, personal growth, positive relations with others, purpose in life, self acceptance) psychological well-being of students in schools of nursing and midwifery, Makurdi?

3) What is the extent of the joint impact of Personality traits and stress in predicting psychological well-being of students in schools of nursing and midwifery, Makurdi?

\section{Hypotheses}

The following hypotheses were formulated for the study:

1) Personality trait (openness, conscientiousness, extraversion, agreeableness, neuroticism) will influence (autonomy, environmental mastery, personal growth, positive relations with others, purpose in life, self acceptance) psychological wellbeing among students in Schools of Nursing and Midwifery, Makurdi.

2) Stress will negatively influence (autonomy, environmental mastery, personal growth, positive relations with others, purpose in life, self acceptance) psychological wellbeing among students in Schools of Nursing and Midwifery, Makurdi.

3) Personality traits and stress will jointly influence psychological well-being among students in Schools of Nursing and Midwifery, Makurdi.

\section{Methodology}

This study employed the Ex Post Facto research design. The method showed relationships amongst the variables in the study. It implies that none of the variables in the study were manipulated. The predictor variables are personality traits subdivided into extraversion, agreeableness, neuroticism, conscientiousness, and openness to experience and stress items designed to tap how unpredictable, uncontrollable, and overloaded respondents find their lives. The criterion variable was psychological well-being which is measured as a single or composite construct and also as a multivariate construct. 
In Ex Post Facto research design, the investigator cannot directly manipulate the variables. In this design, the dependent variable (which in this study was psychological well-being) was observed, while the influence of the several independent variables (in this study are personality traits and stress) are examine. No artificial setting was created in Ex Post Facto research design.

This study was conducted in schools of nursing and midwifery, Makurdi, Benue State. Following the creation of Benue States out of the then, Benue-Plateau and Kwara States in 1976, Makurdi town was made the State Capital. Consequently, the need arose for the establishment of schools of nursing and midwifery in the headquarters (Makurdi). Hence, the schools of nursing and midwifery were fully established in 1978. The schools are situated in the heart of Makurdi boarding Saint Catherine's primary school in the north east of the school, Nativity nursery and primary school in the north, Bureau for local government and chieftaincy affairs and police headquarters in west, High court 9 and Magistrate court in the south.

Initially the schools were situated in the then, General Hospital, Makurdi until its permanent site was completed in 1979. It was a sub-division of the Nursing division of the State ministry of health.

The schools started with one-hundred and seventy-one (171) students; rose up to over seven hundred students until 2012 when it lost its accreditation from Nursing and Midwifery Council of Nigeria (NMCN) due to lack of staff strength and poor infrastructure. However, the schools regained its accreditation in 2016 after Governor Samuel Ortom in 2016 responded to all the challenges facing the school.

The schools currently have a total student's population of 250 and staff strength of 126 (48 academic and 78 non-academics).

The aim of the schools is to train professionally competent and versatile Nursing and Midwifery practitioners who, through initiative and self elevated learning are capable of providing high level care to individuals and expectant families in homes, communities, health centers, hospitals and clinics in the served and underserved areas of Benue State.

The schools has recently been renovated and up graded by the Benue State government.

The participants were comprised of 250 students in schools of nursing and midwifery, Makurdi. The researcher used the entire population for the study since they were of a manageable size. Respondents cut across male and female from year 1, 2, and 3, age between 16-25, 26 years and above. Also, students from different ethnic and religious affiliation were considered for the study.

The researcher did a pre-assessment survey in order to identify the population for the study. Since the population was of a manageable size as suggested by Nwana, (1990). No sampling was done. 
In this study, questionnaires were utilized as the main data source for analysis. Therefore, instruments were formulated to integrate four parts.

Part 'A', consist of demographic variable, part 'B', encompasses measurement of personality domains (BFI), part 'C', measures perceived stress and part ' $\mathrm{D}$ ', measures psychological well-being on a six core dimensions.

The Big Five Inventory (BFI) was developed by John, Donahue and Kentle (1991). The inventory contains 44-items which assess personality from a five-dimensional perspective. The essence of the perspective is that personality characteristics can be classified into five broad dimensions which are distinct from one another. The dimensions or subscales of the BFI are:

Extraversion: High energy and activity level, dominance, sociability, expressiveness and positive emotions.

Agreeableness:Prosocial orientation, altruism, tender mindedness, trust and modesty.

Conscientiousness: Impulse control, task orientation and goal directedness.

Openness: it exemplifies the breadth, depth and complexity of an individual's mental and experiential life.

The scale asked participants to circle a response from a five-point Likert scale ranging from "Disagree strongly" to "Agree strongly" which corresponded best with the extent to which they agreed with the statement.

Scoring: To score the BFI, you will first need to reverse-score all negatively-keyed items. The negative items are 16 items cut across the five dimensions e.g.: Extraversion: 6, 21, 31; Agreeableness: 2, 12, 27, 37; Conscientiousness: 8, 18, 23, 43; Neuroticism: 9, 24, 34; Openness: 35,41 . To record these items, you should subtract your score for all reversescored items from 6. For example, if you gave yourself a 5, compute 6 minus 5 and your recoded score is 1 . That is, a score of 1 becomes 5,2 becomes 4,3 , remains 3,4 remains 3,4 becomes 2 , and 5 becomes 1 .

Next, you will create scale scores by averaging the following items for each B5 domain (where $\mathrm{R}$ indicates using the reverse-scored item).

Extraversion: 1, 6R, 11, 16, 21R, 26, 31R, 36; Agreeableness: 2R, 7, 12R, 17, 22, 27R, 32, 37R, 42; Conscientiousness: 3, 8R, 13, 18R, 23R, 28, 33, 38, 43R; Neuroticism: 4, 9R, 14, 19, 24R, 29, 34R, 39; Finally, Openness: 5, 10, 15, 20, 25, 30, 35R, 40, 41R, 44. (R=2, 6, 8, $9,12,18,21,23,24,27,31,34,35,37,41,43)$ i.e. anyone who select 1 , you code $5,2=4$, $3=3,4=2,5=1$.

John et al.(1991) provided the original psychometric properties of the scale for the American samples while Umeh (2004) provided the properties for Nigerian samples. 
The reliability coefficient Cronbach alpha obtained by John et al. (1991) was .80 and a three month test re-tests reliability .85. The BFI was adapted for the use of professionals in Nigeria after several years of research at re-standardizing it in order to enhance its suitability and relevance for Nigerians. A pilot study to determine the reliability of this instrument for use in the present study yielded a cronbach's alpha of .720 for extraversion, .800 for agreeableness, .750 for conscientiousness, .900 for neuroticism and .880 for openness.

Perceived stress scale (PSS) developed by Cohen, Kamarck, \&Mermelstein (1983) was use to measure respondents' stress. It is a 10-item 5-point likert type scale.

It measures the degree to which situations in one's life are appraised as stressful. Items were designed to tap how unpredictable, uncontrollable, and overloaded respondents find their lives.

The scale also includes a number of direct queries about current levels of experienced stress. The questions in the scale ask about feelings and thoughts during the last month. In each case, respondents were asked how often they felt a certain way.

There were 4 positive and 6 negative items in the scale. For the positive items respondents got '4' for never, ' 3 ' for almost never, ' 2 ' for sometimes, ' 1 ' for fairly often, ' 0 ' for very often responses.

For the negative items, scoring was in reverse order. The sum of scores of all items was the total score of the scale with a range of 0 to 40 for an individual. The higher the score, the higher is the perceived stress.

Items 4, 5, 7, 8 are in a reverse scores. Total Perceived Stress: Sum items: 1, 2, 3, 4R, 5R, 6, 7R, 8R, 9, \& 10 .

PSS-10 scores are obtained by reversing the scores on the four positive items, e.g., $0=4,1=3$, $2=2,3=1,4=0$ and then summing across all 10 items. Items $4,5,7$, and 8 are the positively stated items.

Reliability reported Cronbach's $\propto$ between $.84-.86$ for the PSS. Validity correlation of the PSS to other measures of similar symptoms ranges between .52-.76 (Cohen, et al, 1983). Some Nigerian researchers have also found sufficient evidence for the reliability of the PSS with Nigerian subjects (Azeez\&Adenuga, 2012). In their study, a Cronbach's alpha of 0.72 and a Guttman Split-half reliability coefficient of 0.77 were reported for the scale. A pilot study to determined the reliability of this instrument for use in the present study yielded a cronbach's alpha of .740

Ryff Scales of Psychological Well-Being was developed by Ryff and Keyes (1998). With six dimensions, it consists of 42 items ( 7 per scale) measured on 1-6 point likert scale $1=$ indicating strongly disagree, $2=$ disagree somewhat, $3=$ disagree slightly, $4=$ agree slightly, $5=$ agree somewhat, $6=$ strongly agree. With internal consistency alpha cronchbach of the following after test-retest; Self-acceptance .93 and 85, Positive Relations with others .91 and 83, Autonomy .83 and .88 , Environmental Mastery $=.90$ and 81, Purpose in Life $=90$ and 82, Personal Growth $=87$ and 81 . 
Journal DOI: www.doi.org/10.46654/ij.24889849

Article DOI: www.doi.org/10.46654/ij.24889849.e7572

The specific 7-items scales include: Autonomy (PWBAU: $1+2+3+4+5+6+7$ ); Environmental Mastery (PWBEM: $8+9+10+11+12+13+14)$; Personal Growth (PWBPG: $15+16+17+18+19+20+21$ ); Positive Relation with Others (PWBPR: $22+23+24+25+26+27+28$ ); Purpose in life (PWBPU: $29+30+31+32+33+34+35$ ); SelfAcceptance (PWBSA: $36+37+38+39+40+41+42$ ).

In scoring, reverse items $5,6,7,12,13,14,17,18,19,20,21,26,27,28,31,32,33,34,35$, 40, 41, 42 are in a reverse-coded so that high scores reflect higher standing in the scale. For an item with a missing value, the mean value of completed items is imputed. (I.e. anyone who selects any of the reverse items 1 becomes $6,2=5,3=4,4=3,5=2,6=1$ )

Items from the separate scales are mixed (by taking one item from each scale successively into one continuous self-report instrument).

Responses to negatively scored items (-) are reversed in the final scoring procedures so that high scores indicate high self-rating on the dimension assessed. A pilot study to determine the reliability of this instrument for use in the present study yielded a cronbach's alpha of .720 for autonomy, .710 for environmental mastery, .690 for personal growth, .870 for positive relations with others, .710 for purpose in life and .810 for self-acceptance.

\section{RESULTS}

Results focused on the testing of research hypotheses and presentation of results of data analyzed.

\section{Test of Research Hypotheses}

Hypothesis 1(a) stated that personality traits will influence psychological well-being (autonomy) among students in School of Nursing Makurdi. This hypothesis was tested using simple linear regression and the result is presented in table (1a).

Table (1a). Simple linear regression showing influence of personality traits on psychological well-being (autonomy) among students in Schools of Nursing and Midwifery Makurdi

\begin{tabular}{|c|c|c|c|c|c|c|}
\hline Variable & $\mathbf{R}$ & $\mathbf{R}^{2}$ & $\boldsymbol{\beta}$ & $\mathbf{F}$ & $\mathbf{t}$ & $\mathbf{P}$ \\
\hline Constant & .891 & .795 & .4 .554 & 181.093 & 2.818 & .005 \\
\hline \multicolumn{2}{|c|}{ Extraversion } & & .009 & & .269 & .788 \\
\hline \multicolumn{2}{|c|}{ Conscientiousness } & & .454 & & 14.101 & .000 \\
\hline \multicolumn{2}{|c|}{ Neuroticism } & & .358 & & 10.850 & .000 \\
\hline \multicolumn{2}{|l|}{ Openness } & & .389 & & 11.941 & .000 \\
\hline \multicolumn{2}{|c|}{ Agreeableness } & & -.014 & & -.446 & .656 \\
\hline
\end{tabular}


Journal DOI: www.doi.org/10.46654/ij.24889849

Article DOI: www.doi.org/10.46654/ij.24889849.e7572

The result in table (1a) indicated that personality traits influence psychological wellbeing among students in Schools of Nursing and Midwifery, Makurdi $[F(5,239)=181.093$, $\mathrm{P}<.001]$. The result further showed that personality traits accounted for $79.5 \%$ variance in psychological well-being of students in schools of nursing and midwifery. On their individual contribution, conscientiousness $(\beta=.454, \mathrm{t}=14.101, \mathrm{P}<.001)$ made the highest positive contribution to the variance in psychological well-being observed among students, openness $(\beta=.389, \mathrm{t}=11.941, \mathrm{P}<.001)$ followed with significant positive contribution to the model, neuroticism $(\beta=.358, \mathrm{t}=10.850, \mathrm{P}<.001)$ also contributed significantly and positively to the variance in psychological well-being among students, while agreeableness $(\beta=-.014, \mathrm{t}=-$ $.446, \mathrm{P}>.05)$ and extraversion $(\beta=.009, \mathrm{t}=.269, \mathrm{P}>.05)$ did not contribute significantly to the observed variance in psychological well-being among students. Based on this finding, hypothesis (1a) was confirmed for conscientiousness, openness and neuroticism.

Hypothesis (1b) stated that personality traits will influence psychological well-being (environmental mastery) among students in Schools of Nursing and Midwifery Makurdi. This hypothesis was tested using simple linear regression and the result is presented in table (1b)

Table (1b) Simple linear regression showing prediction of personality traits on psychological well-being (environmental mastery) among students in Schools of Nursing and Midwifery Makurdi

\begin{tabular}{|c|c|c|c|c|c|c|}
\hline Variable & $\mathbf{R}$ & $\overline{\mathbf{R}^{2}}$ & $\boldsymbol{\beta}$ & $\mathbf{F}$ & $\mathbf{t}$ & $\mathbf{P}$ \\
\hline Constant & .699 & .489 & 6.133 & 44.720 & 2.998 & .000 \\
\hline \multicolumn{2}{|c|}{ Extraversion } & & -.018 & & -.348 & .728 \\
\hline \multicolumn{2}{|c|}{ Conscientiousness } & & .482 & & 9.486 & .000 \\
\hline \multicolumn{2}{|c|}{ Neuroticism } & & .177 & & 3.392 & .001 \\
\hline \multicolumn{2}{|l|}{ Openness } & & .254 & & 4.935 & .000 \\
\hline \multicolumn{2}{|c|}{ Agreeableness } & & .043 & & .849 & .397 \\
\hline
\end{tabular}

\section{$R=.699, R^{2}=.489$ and Adjusted $R^{2}=.478$}

The result in table (1b) showed that personality traits influence psychological wellbeing among students in Schools of Nursing and Midwifery, Makurdi $[F(5,239)=44.720$, $\mathrm{P}<.001]$. Further observation revealed that personality traits accounted for $48.9 \%$ variance in psychological well-being among students in schools of nursing and midwifery. On their independent contribution, conscientiousness $(\beta=.482, \mathrm{t}=9.486, \mathrm{P}<.001)$ made a positive and significant contribution to the observed variance in psychological well-being of students, openness $(\beta=.254, \mathrm{t}=4.935, \mathrm{P}<.001)$ contributed significantly and positively to psychological well-being among students, neuroticism $(\beta=.177, \mathrm{t}=3.392, \mathrm{P}<.001)$ also contributed significantly to the variance in psychological well-being among students, while extraversion $(\beta=-.018, \mathrm{t}=-.348, \mathrm{P}>.05$ and agreeableness $(\beta=.043, \mathrm{t}=.849, \mathrm{P}>.05$ did not make significant contribution to the observed variance in psychological well-being. Based on this result, hypothesis (1b) was upheld for conscientiousness, openness and neuroticism. 
Journal DOI: www.doi.org/10.46654/ij.24889849

Article DOI: www.doi.org/10.46654/ij.24889849.e7572

Hypothesis (1c) stated that personality traits will influence psychological well-being (personal growth) among students in Schools of Nursing and Midwifery Makurdi. This hypothesis was tested using simple linear regression and the result is presented in table (1c)

Table (1c). Simple linear regression showing prediction of personality traits on psychological well-being (personal growth) among students in Schools of Nursing and Midwifery Makurdi

\begin{tabular}{|c|c|c|c|c|c|c|}
\hline Variable & $\mathbf{R}$ & $\mathbf{R}^{2}$ & $\bar{\beta}$ & $\mathbf{F}$ & $\mathbf{t}$ & $\mathbf{P}$ \\
\hline Constant & .780 & .608 & 4.973 & 71.964 & 2.399 & .000 \\
\hline \multicolumn{2}{|c|}{ Extraversion } & & .048 & & 1.049 & .295 \\
\hline \multicolumn{2}{|c|}{ Conscientiousness } & & .495 & & 11.076 & .000 \\
\hline \multicolumn{2}{|c|}{ Neuroticism } & & .228 & & 4.990 & .000 \\
\hline \multicolumn{2}{|l|}{ Openness } & & .310 & & 6.866 & .000 \\
\hline \multicolumn{2}{|c|}{ Agreeableness } & & -.006 & & -.128 & .899 \\
\hline
\end{tabular}

$R=.780, R^{2}=.608$ and Adjusted $R^{2}=.600$

The result in table (1c) showed that conscientiousness, neuroticism, and openness significantly influence psychological well-being among students in Schools of Nursing and Midwifery, Makurdi $[\mathrm{F}(5,237)=71.964, \mathrm{P}<.001]$. The result further revealed that $60.8 \%$ of the total variance in the psychological well-being of the students was been accounted for by the personality traits. The result also suggested that, only conscientiousness $(\beta=.495, \mathrm{t}=$ 11.076, $\mathrm{P}<.001)$, neuroticism $(\beta=.228 \mathrm{t}=4.990, \mathrm{P}<.001)$ and openness $(\beta=.310, \mathrm{t}=6.866$, $\mathrm{P}<.001)$ significantly and positively predicted psychological well-being. The implication of this result is that, extraversion $(\beta=.048, \mathrm{t}=1.049, \mathrm{P}>.05)$ and agreeableness $(\beta=-.006, \mathrm{t}=-$ $.128, \mathrm{P}>.05)$ did not significantly and positively predict psychological well-being among students. Based on this result, hypothesis (1c) was confirmed for conscientiousness, neuroticism and openness.

Hypothesis (1d) stated that personality traits will significantly and positively influence psychological well-being (positive relations with others) among students in Schools of Nursing and Midwifery Makurdi. This hypothesis was tested using simple linear regression and the result is presented in table (1d) 
Journal DOI: www.doi.org/10.46654/ij.24889849

Article DOI: $\underline{\text { www.doi.org/10.46654/ij.24889849.e7572 }}$

Table (1d) Simple linear regression showing prediction of personality traits on psychological well-being (positive relations with others) among students in Schools of Nursing and Midwifery Makurdi

\begin{tabular}{|c|c|c|c|c|c|c|}
\hline Variable & $\mathbf{R}$ & $\overline{\mathbf{R}^{2}}$ & $\beta$ & $\mathbf{F}$ & $\mathbf{t}$ & $\mathbf{P}$ \\
\hline Constant & .789 & .622 & 6.356 & 77.131 & 2.958 & .000 \\
\hline \multicolumn{2}{|c|}{ Extraversion } & & -.011 & & -.251 & .802 \\
\hline \multicolumn{2}{|c|}{ Conscientiousness } & & .260 & & 5.948 & .000 \\
\hline \multicolumn{2}{|c|}{ Neuroticism } & & .369 & & 8.240 & .000 \\
\hline \multicolumn{2}{|l|}{ Openness } & & .422 & & 9.557 & .000 \\
\hline \multicolumn{2}{|c|}{ Agreeableness } & & -.006 & & -.143 & .887 \\
\hline
\end{tabular}

Findings from table (1d) showed that personality traits significantly predicted psychological well-being $[\mathrm{F}(5,239)=77.131, \mathrm{P}<.001]$. Among the personality traits, only conscientiousness $(\beta=.260, \mathrm{t}=5.948, \mathrm{P}<.001)$, neuroticism $(\beta=.369, \mathrm{t}=8.240, \mathrm{P}<.001)$ and openness $(\beta=.422, \mathrm{t}=9.577, \mathrm{P}<.001)$ significantly and positively predicted psychological well-being among students. While extraversion $(\beta=-.011, \mathrm{t}=-.251, \mathrm{P}>.05)$ and agreeableness $(\beta=-.006, \mathrm{t}=-.143, \mathrm{P}>.05)$ did not significantly contributed to the model. The result also showed that $62.2 \%$ of the total variance in psychological well-being of the students is explained by personality traits. Based on this finding, hypothesis (1d) was upheld for conscientiousness, neuroticism and openness.

Hypothesis (1e) stated that personality traits will influence psychological well-being (purpose in life) among students in Schools of Nursing and Midwifery Makurdi. This hypothesis was tested using multiple linear regression and the result is presented in table (1e).

Table (1e) Simple linear regression showing influence of personality traits on psychological well-being (purpose in life) among students in Schools of Nursing and Midwifery Makurdi

\begin{tabular}{|c|c|c|c|c|c|c|}
\hline Variable & $\mathbf{R}$ & $\mathbf{R}^{2}$ & $\beta$ & $\mathbf{F}$ & $\mathbf{t}$ & $\mathbf{P}$ \\
\hline Constant & .731 & .534 & 5.501 & 53.709 & 2.708 & .000 \\
\hline \multicolumn{2}{|c|}{ Extraversion } & & -.003 & & -.070 & .944 \\
\hline \multicolumn{2}{|c|}{ Conscientiousness } & & .430 & & 8.855 & .000 \\
\hline \multicolumn{2}{|c|}{ Neuroticism } & & .145 & & 2.912 & .004 \\
\hline \multicolumn{2}{|l|}{ Openness } & & .422 & & 9.557 & .000 \\
\hline \multicolumn{2}{|c|}{ Agreeableness } & & .386 & & 7.869 & .000 \\
\hline
\end{tabular}


Findings in table (1e) revealed that personality traits influenced psychological wellbeing $[\mathrm{F}(5,239)=53.709, \mathrm{P}<.001]$. The result also showed that personality traits accounts for $53.4 \%$ of the total variance in psychological well-being of students. The result also indicated that among the personality traits, only extraversion $(\beta=-.003, \mathrm{t}=-.070, \mathrm{P}>.05)$ that did not significantly predict psychological well-being among students, while conscientiousness $(\beta$ $=.430, \mathrm{t}=8.855, \mathrm{P}<.001)$, neuroticism $(\beta=.145, \mathrm{t}=2.912, \mathrm{P}<.05)$, openness $(\beta=.422, \mathrm{t}=9.557$, $\mathrm{P}<.001)$ and agreeableness $(\beta=.386, \mathrm{t}=7.869, \mathrm{P}<.001)$ contributed significantly and positively to the variance in psychological well-being of students in Schools of Nursing and Midwifery. With this result, hypothesis (1e) was confirmed except for extraversion.

Hypothesis (1f) stated that personality traits will influence psychological well-being (self-acceptance) among students in Schools of Nursing and Midwifery Makurdi. This hypothesis was tested using simple linear regression and the result is presented in table (1f)

Table (1f) Simple linear regression showing influence of personality traits on psychological well-being (self-acceptance) among students in Schools of Nursing and Midwifery Makurdi

\begin{tabular}{|c|c|c|c|c|c|c|}
\hline Variable & $\mathbf{R}$ & $\overline{\mathbf{R}^{2}}$ & $\beta$ & $\mathbf{F}$ & t & $\mathbf{P}$ \\
\hline Constant & .618 & .384 & 10.280 & 28.625 & 2.730 & .000 \\
\hline \multicolumn{2}{|c|}{ Extraversion } & & .051 & & .912 & .363 \\
\hline \multicolumn{2}{|c|}{ Conscientiousness } & & .029 & & .552 & .582 \\
\hline \multicolumn{2}{|c|}{ Neuroticism } & & -.039 & & -.748 & .460 \\
\hline \multicolumn{2}{|l|}{ Openness } & & .623 & & 11.957 & .000 \\
\hline \multicolumn{2}{|c|}{ Agreeableness } & & -.042 & & -.740 & .460 \\
\hline
\end{tabular}

$\mathrm{R}=.618, \mathrm{R}^{2}=.384$ and Adjusted $\mathrm{R}^{2}=.368$

The result in table (1f) showed that personality traits influenced psychological wellbeing $[\mathrm{F}(2,237)=28.625, \mathrm{P}<.001]$. On their individual contribution, only openness $(\beta=$ $.623, \mathrm{t}=11.957, \mathrm{P}<.001)$ contributed significantly to the observed variance in psychological well-being among students, while, extraversion $(\beta=.051, \mathrm{t}=.912, \mathrm{P}>.05)$, conscientiousness $(\beta$ $=.029, \mathrm{t}=.552, \mathrm{P}>.05)$, neuroticism $(\beta=-.039, \mathrm{t}=-.748, \mathrm{P}>.05)$ and agreeableness $(-.042, \mathrm{t}=-$ $.740, \mathrm{P}>.05)$ did not significantly contribute to the model. The result also revealed that personality traits accounted for $38.4 \%$ of the total variance in psychological well-being among students in schools of nursing and midwifery. With this result, hypothesis six was upheld only for openness.

Hypothesis (2a) stated that stress will negatively influence psychological well-being (autonomy) among students in schools of Nursing and Midwifery Makurdi. This hypothesis was tested using simple linear regression and the result is presented in table (2a). 
Journal DOI: www.doi.org/10.46654/ij.24889849

Article DOI: www.doi.org/10.46654/ij.24889849.e7572

Table (2a) Simple linear regression showing influence of stress on psychological wellbeing (autonomy) among students in Schools of Nursing and Midwifery Makurdi

\begin{tabular}{|c|c|c|c|c|c|c|}
\hline Variables & $\mathbf{R}$ & $\overline{\mathbf{R}^{2}}$ & $\beta$ & $\mathbf{F}$ & $\mathbf{t}$ & $\mathbf{P}$ \\
\hline Constant & .035 & .001 & 14.763 & .309 & 5.371 & .000 \\
\hline Stress & & & .035 & & .556 & .579 \\
\hline
\end{tabular}

$R=.035, R^{2}=.001$ and Adjusted $R^{2}=-.003$

The result in table (2a) indicated that stress did not negatively influence psychological wellbeing $[\mathrm{F}(1,249)=.309, \mathrm{P}>.05]$. Based on this finding, hypothesis seven was rejected.

Hypothesis (2b) stated that stress will negatively influence psychological well-being (environmental mastery) among students in Schools of Nursing and Midwifery Makurdi. This hypothesis was tested using simple linear regression and the result is presented in table $(2 b)$

Table (2b) Simple linear regression showing influence of stress on psychological wellbeing (environmental mastery) among students in Schools of Nursing and Midwifery Makurdi.

\begin{tabular}{lllcccc}
\hline Variables & $\mathbf{R}$ & $\mathbf{R}^{2}$ & $\boldsymbol{\beta}$ & $\mathbf{F}$ & $\mathbf{t}$ & $\mathbf{P}$ \\
\hline Constant & .515 & .265 & 9.735 & 89.629 & 17.279 & .000 \\
Stress & & & & & & \\
\hline
\end{tabular}

$R=.515, R^{2}=.265$ and Adjusted $R^{2}=.262$

Finding in table (2b) showed that stress positively influenced psychological well-being [F $(1,249)=89.629, \mathrm{P}<.001$.] The result further indicated that stress accounted for $26.5 \%$ of the total variance in psychological well-being among students in Schools of Nursing and Midwifery. With this result, hypothesis (2b) was rejected.

Hypothesis (2c) stated that stress will negatively influence psychological well-being (personal growth) among students in Schools of Nursing and Midwifery Makurdi. This hypothesis was tested using simple linear regression and the result is presented in table (2c).

Table (2c) Simple linear regression showing influence of stress on psychological wellbeing (personal growth) among students in Schools of Nursing and Midwifery Makurdi

\begin{tabular}{lllllll}
\hline Variables & $\mathbf{R}$ & $\mathbf{R}^{2}$ & $\boldsymbol{\beta}$ & $\mathbf{F}$ & $\mathbf{t}$ & $\mathbf{P}$ \\
\hline Constant & .126 & .016 & 10.843 & 3.991 & 4.273 & .000 \\
Stress & & & & & & 1.998 \\
\hline
\end{tabular}

$R=.126, R^{2}=.016$ and Adjusted $R^{2}=.012$

The result in table (2c) showed that stress positively influenced psychological wellbeing $[\mathrm{F}(1,247)=3.991, \mathrm{P}<.05]$. Further observation indicated that only $1.6 \%$ variance in 
Journal DOI: www.doi.org/10.46654/ij.24889849

Article DOI: www.doi.org/10.46654/ij.24889849.e7572

psychological well-being of students in Schools of Nursing and Midwifery was being accounted for by stress. With this result hypothesis (2c) was rejected.

Hypothesis (2d) stated that stress will negatively influence psychological well-being (positive relation) among students in Schools of Nursing and Midwifery Makurdi. This hypothesis was tested using simple linear regression and the result is presented in table (2d).

Table (2d) Simple linear regression showing influence of stress on psychological well-being (positive relation) among students in Schools of Nursing and Midwifery Makurdi

\begin{tabular}{lllcrcc}
\hline Variables & $\mathbf{R}$ & $\mathbf{R}^{2}$ & $\boldsymbol{\beta}$ & $\mathbf{F}$ & $\mathbf{t}$ & $\mathbf{P}$ \\
\hline Constant & .008 & .000 & 15.827 & .897 & 5.854 & .000 \\
Stress & & & & & & .129 \\
\hline
\end{tabular}

$R=.008, R^{2}=.000$ and Adjusted $R^{2}=-.004$

The result in table (2d) revealed that stress did not negatively influenced psychological well-being $[\mathrm{F}(1,249)=.017, \mathrm{P}>.05$.] Based on this finding, hypothesis $(2 \mathrm{~d})$ was rejected.

Hypothesis (2e) stated that stress will negatively influence psychological well-being (purpose in life) among students in Schools of Nursing and Midwifery Makurdi. This hypothesis was tested using simple linear regression and the result is presented in table (2e)

Table (2e) Simple linear regression showing result for prediction of stress on psychological well-being (purpose in life) among students in Schools of Nursing and Midwifery Makurdi

\begin{tabular}{lllllll}
\hline Variables & $\mathbf{R}$ & $\mathbf{R}^{2}$ & $\boldsymbol{\beta}$ & $\mathbf{F}$ & $\mathbf{t}$ & $\mathbf{P}$ \\
\hline Constant & .051 & .003 & 12.743 & .420 & 5.854 & .000 \\
Stress & & & & & & .808 \\
\hline
\end{tabular}

$R=.0051, R^{2}=.003$ and Adjusted $R^{2}=-.001$

The result in table (2e) showed that stress did not negatively influence psychological well-being among students in Schools of Nursing and Midwifery, Makurdi. [F $(1,249)=$ $.652, \mathrm{P}>.05]$. Based on this finding, hypothesis (2e) was rejected.

Hypothesis (2f) stated that stress will negatively influence psychological well-being (self-acceptance) among students in Schools of Nursing and Midwifery Makurdi. This hypothesis was tested using simple linear regression and the result is presented in table (2f). 
Journal DOI: www.doi.org/10.46654/ij.24889849

Article DOI: $\underline{\text { www.doi.org/10.46654/ij.24889849.e7572 }}$

Table (2f) Simple linear regression showing result for influence of stress on psychological well-being (self-acceptance) among students in Schools of Nursing and Midwifery Makurdi

\begin{tabular}{lllllll}
\hline Variables & $\mathbf{R}$ & $\mathbf{R}^{2}$ & $\boldsymbol{\beta}$ & $\mathbf{F}$ & $\mathbf{t}$ & $\mathbf{P}$ \\
\hline Constant & .099 & .010 & 11.861 & .119 & 4.699 & .000 \\
& & & & & & \\
Stress & & & & .099 & & 1.565 \\
.119 & & & & & & \\
\hline
\end{tabular}

$R=.099, R^{2}=.010$ and Adjusted $R^{2}=-.006$

Finding in table (2f) revealed that stress did not positively influence psychological well-being among students in Schools of Nursing and Midwifery, Makurdi. [F $(1,247)=.017$, $\mathrm{P}>$.05]. With this result, hypothesis (2f) was rejected.

Hypothesis (3a) stated that personality traits and stress will jointly influence psychological well-being (autonomy) among students in Schools of Nursing and Midwifery Makurdi. This hypothesis was tested using multiple linear regressions and the result is presented in table (3a)

Table (3a) multiple linear regression showing result for joint influence of personality traits and stress on psychological well-being (autonomy) among students in Schools of Nursing and Midwifery Makurdi

\begin{tabular}{lllllll}
\hline Variables & $\mathbf{R}$ & $\mathbf{R}^{2}$ & $\boldsymbol{\beta}$ & $\mathbf{F}$ & $\mathbf{t}$ & $\mathbf{P}$ \\
\hline Constant & .061 & .004 & 18.402 & .641 & 3.629 & .000 \\
Personality & & & -.054 & & -.813 & .417 \\
Stress & & & .044 & & .659 & .511 \\
\hline
\end{tabular}

$R=.061, R^{2}=.004$ and Adjusted $R^{2}=-.005$

Findings in table (3a) revealed that personality traits and stress did not jointly influence psychological well-being among students in Schools of Nursing and Midwifery, Makurdi. $[\mathrm{F}(2,239)=.445, \mathrm{P}>.05]$. Based on this finding, hypothesis (3a) was rejected.

Hypothesis (3b) stated that personality traits and stress will jointly influence psychological well-being (environmental mastery) among students in Schools of Nursing and Midwifery Makurdi. This hypothesis was tested using multiple linear regressions and the result is presented in table (3b) 
Journal DOI: www.doi.org/10.46654/ij.24889849

Article DOI: www.doi.org/10.46654/ij.24889849.e7572

Table (3b) multiple linear regression showing result for joint influence of personality traits and stress on psychological wellbeing (environmental mastery) among students in Schools of Nursing and Midwifery Makurdi

\begin{tabular}{lllllll}
\hline Variables & $\mathbf{R}$ & $\mathbf{R}^{\mathbf{2}}$ & $\boldsymbol{\beta}$ & $\mathbf{F}$ & $\mathbf{t}$ & $\mathbf{P}$ \\
\hline Constant & .309 & .001 & 12.573 & .838 & 3.088 & .002 \\
Personality & & & .007 & & .110 & .912 \\
Stress & & & .036 & & .542 & .588 \\
\hline
\end{tabular}

$R=.309, R^{2}=.001$ and Adjusted $R^{2}=-.007$

Findings in table (3b) established that personality traits and stress did not jointly influence psychological well-being among students in Schools of Nursing and Midwifery, Makurdi. $[\mathrm{F}(2,239)=.177, \mathrm{P}>.05]$. Based on this finding, hypothesis $(3 \mathrm{~b})$ was rejected.

Hypothesis (3c) stated that personality traits and stress will jointly predict psychological well-being (personal growth) among students in Schools of Nursing and Midwifery Makurdi. This hypothesis was tested using multiple linear regressions and the result is presented in table $(3 \mathrm{c})$

Table (3c) multiple linear regression showing result for joint influence of personality traits and stress on psychological well-being (personal growth) among students in Schools of Nursing and Midwifery Makurdi

\begin{tabular}{llccccc}
\hline Variables & $\mathbf{R}$ & $\mathbf{R}^{\mathbf{2}}$ & $\boldsymbol{\beta}$ & $\mathbf{F}$ & $\mathbf{t}$ & $\mathbf{P}$ \\
\hline Constant & .132 & .017 & 13.928 & .126 & 2.979 & .003 \\
Personality & & & -.050 & & -.756 & .420 \\
Stress & & & .135 & & 2.024 & .044 \\
\hline
\end{tabular}

$R=.132, R^{2}=.017$ and Adjusted $R^{2}=.009$

The result in table (3c) showed that personality traits and stress did not jointly influence psychological well-being among students in Schools of Nursing and Midwifery, Makurdi. $[\mathrm{F}(2,237)=2.087, \mathrm{P}>.05]$. With this result, hypothesis $(3 \mathrm{c})$ was rejected.

Hypothesis (3d) stated that personality traits and stress will significantly and jointly influence psychological well-being (positive relation) among students in Schools of Nursing and Midwifery Makurdi. This hypothesis was tested using multiple linear regressions and the result is presented in table $(3 \mathrm{~d})$ 
Journal DOI: www.doi.org/10.46654/ij.24889849

Article DOI: www.doi.org/10.46654/ij.24889849.e7572

Table (3d) multiple linear regression showing result for joint influence of personality traits and stress on psychological well-being (positive relation) among students in Schools of Nursing and Midwifery Makurdi

\begin{tabular}{lllllll}
\hline Variables & $\mathbf{R}$ & $\mathbf{R}^{\mathbf{2}}$ & $\boldsymbol{\beta}$ & $\mathbf{F}$ & $\mathbf{t}$ & $\mathbf{P}$ \\
\hline Constant & .048 & .002 & 19.022 & .761 & 3.823 & .000 \\
Personality & & & & & & \\
Stress & & & .049 & & -.735 & .463 \\
\hline
\end{tabular}

$R=.048, R^{2}=.002$ and Adjusted $R^{2}=-.006$

Table (3d) indicated that personality traits and stress did not jointly influence psychological well-being among students in schools of Nursing and Midwifery, Makurdi [F $(2,239)=.274, \mathrm{P}>.05]$. With this result, hypothesis $(3 \mathrm{~d})$ was rejected.

Hypothesis (3e) stated that personality traits and stress will jointly influence psychological well-being (purpose in life) among students in Schools of Nursing and Midwifery Makurdi. This hypothesis was tested using multiple linear regressions and the result is presented in table $(3 \mathrm{e})$

Table (3e) multiple linear regression showing result for joint influence of personality traits and stress on psychological wellbeing (purpose in life) among students in Schools of Nursing and Midwifery Makurdi

\begin{tabular}{lllllll}
\hline Variables & $\mathbf{R}$ & $\mathbf{R}^{2}$ & $\boldsymbol{\beta}$ & $\mathbf{F}$ & $\mathbf{t}$ & $\mathbf{P}$ \\
\hline Constant & .060 & .004 & 11.589 & .653 & 2.738 & .007 \\
Personality & & & .018 & & .273 & .785 \\
Stress & & & .053 & & .792 & .429 \\
\hline
\end{tabular}

$R=.060, R^{2}=.004$ and Adjusted $R^{2}=-.005$

The result in table (3e) revealed that personality traits and stress did not jointly influence psychological well-being among students in Schools of Nursing and Midwifery, Makurdi $[\mathrm{F}(2,239)=.426, \mathrm{P}>.05$. Based on this finding, hypothesis $(3 \mathrm{e})$ was rejected.

Hypothesis (3f) stated that personality traits and stress will jointly influence psychological well-being (self-acceptance) among students in Schools of Nursing and Midwifery Makurdi. This hypothesis was tested using multiple linear regressions and the result is presented in table (3f) 
Journal DOI: www.doi.org/10.46654/ij.24889849

Article DOI: www.doi.org/10.46654/ij.24889849.e7572

Table (3f) multiple linear regression showing result for joint influence of personality traits and stress on psychological well-being (self-acceptance) among students in Schools of Nursing and Midwifery Makurdi

\begin{tabular}{lllcccc}
\hline Variables & $\mathbf{R}$ & $\mathbf{R}^{\mathbf{2}}$ & $\boldsymbol{\beta}$ & $\mathbf{F}$ & $\mathbf{t}$ & $\mathbf{P}$ \\
\hline Constant & .131 & .017 & 17.211 & .133 & 2.738 & .000 \\
Personality & & & & & & -1.363 \\
Stress & & & .091 & & & .174 \\
\hline
\end{tabular}

$R=.131, R^{2}=.017$ and Adjusted $R^{2}=.009$

Findings in table (3f) indicated that personality traits and stress did not jointly influence psychological well-being $[\mathrm{F}(2,239)=2.039, \mathrm{P}>.05]$. With this result hypothesis (3f) was rejected.

\section{DISCUSSION}

The first hypothesis tested that; personality traits (openness, conscientiousness, extraversion, agreeableness, neuroticism) will influence psychological well-being (autonomy) among students in Schools of Nursing and Midwifery, Makurdi. Hypothesis (1a) was accepted for conscientiousness, openness and neuroticism. This implies that the tendency of the students to have a sense of achievement and to be dependable (conscientiousness), the tendency to exhibit poor emotional adjustment such as anxiety, impulsivity and fear (neuroticism) and the tendency to be creative and curious (openness) significantly predict psychological well-being (autonomy). This further shows that the more the tendency to have a sense of achievement and to be dependable, the tendency to exhibit poor emotional adjustment such as anxiety, impulsivity and fear and the tendency to be creative and curious the higher their self determination and independence in making their own decisions. This study is in line with Van Dierendonck (2005) who conducted a second order factor analysis of the big five and the Ryff scale (1989) and found autonomy and openness having a positive relationship. The finding is also consistent with Creed and Watson (2009) who found neuroticism to significantly predict the psychological well-being among middle-aged and matured unemployed. Also, Shultz (2008) found a relation between neuroticism and psychological well-being. Psychological well-being dimensions showed a slightly stronger relationship with the big 5. Furthermore, Butkovic et al., (2012) likewise reported that, personality traits explained more variance in psychological well-being. In addition, consistent with Schmutte and Ryff (1997), psychological well-being showed a more diverse relationship with personality traits. Previous studies have also primarily identified an association between neuroticism and autonomy (Grant et al., 2009; Schmutte \& Ryff, 1997). Perhaps, reflecting the focus of autonomy items on a lack of care for what others think or low selfconsciousness. However, there is also arguably an implicit assumption that autonomy involves some degree of independent thinking. Items captured self-confidence and as well as a spectrum of not being excessively influenced by others to more extreme independence of thought. The Ryff scale measures a relatively social conception of autonomy. While much of the autonomy construct captures positive aspects, there is an aspect that might actually result in less well-being. For instance, not listening to the views of others, never sacrificing one's needs for the needs of others, or an inability to accept the rituals and values of a society could 
have a range of negative consequences. Similarly, some individuals may place less value on Independence of thought thereby further reducing the relationship between autonomy and well-being. However, this work contracted the work of Siegler and Brummett (2008) who found neuroticism to negatively predicted psychological well-being. In contrast, agreeableness and extraversion was the lowest predictor of psychological well-being among students in Schools of Nursing and Midwifery, Makurdi. The results reinforce the notion that, the key dispositional predictors on psychological well-being vary across well-being dimensions (Grant et al., 2009).

Hypothesis (1b) of the study tested to find out if personality traits will influence psychological well-being (environmental mastery) among students in Schools of Nursing and Midwifery, Makurdi. This finding was accepted for conscientiousness, openness and neuroticism. This is consistent with previous work supporting a stronger relationship between conscientiousness, openness, neuroticism and psychological well-being (Butkovic et al., 2012; Grant et al., 2009) reinforces the distinctiveness of these dimensions. The finding is also in line with the work of Haslam, Whelan and Bastian (2009) who found conscientiousness and openness to be the strongest predictors of well-being, except neuroticism which contracted my findings to positively predicted psychological well-being. Haslan et al., (2009) found neuroticism to negatively predicted psychological well-being. This shows that students on this dimension of psychological well-being of environmental mastery posses the characteristics of creating a surrounding context that suits one's personal needs and capacities. It also involves managing the environment by controlling complex situations and making effective use of opportunities. Students who are high on these dimensions will do well on psychological well-being (environmental mastery).

In Hypothesis (1c), it tested to find out if personality traits will influence psychological well-being (personal growth) among students in Schools of Nursing and Midwifery, Makurdi. It was accepted for conscientiousness, neuroticism and openness on psychological well-being (personal growth) among students in Schools of Nursing and Midwifery, Makurdi. This is also in consonance with Hicks (2007), who found openness and neuroticism showing a higher level of relationship with psychological well-being. Also, Bardi and Ryff (2007) similarly reported that individuals who were higher on openness and lower on neuroticism reported higher personal growth. Standardized betas showed that personal growth was predicted by all five traits, with openness emerging as the strongest predictor. This strong relationship between personal growth and openness is consistent with Schmutte and Ryff (1997). The study is also in line with Steel, Schmidt \& Shultz (2008); they found neuroticism having an association with psychological well-being. They suggested that extraversion (the tendency to be bold, talkative, enthusiastic, and sociable) and neuroticism (the tendency to be emotionally unstable and prone to negative emotions) are especially strong predictors of well-being.

Result of Hypothesis (1d) was accepted. Conscientiousness, neuroticism and openness influenced psychological well-being (positive relations with others) among students in Schools of Nursing and Midwifery, Makurdi. Consistent with this, previous studies have primarily linked positive relations to conscientiousness and openness (Grant et al., 2009; Schmutte \& Ryff, 1997). Also, Kokko, Tolvanen and Pulkkinen (2013) found neuroticism, conscientiousness and openness having a stronger relationship with psychological well-being 
Journal DOI: www.doi.org/10.46654/ij.24889849

Article DOI: www.doi.org/10.46654/ij.24889849.e7572

among middle adulthood. On the contrary, findings by Tashiro and Frazier (2003); Sheikh (2004) found no relationship between conscientiousness and well-being.

In Hypothesis (1e), it tested that personality traits will influence psychological wellbeing (purpose in life) among students in Schools of Nursing and Midwifery, Makurdi. It was found that conscientiousness, neuroticism, openness and agreeableness except extraversion significantly and positively predicted psychological well-being (purpose in life) among students in Schools of Nursing and Midwifery, Makurdi. The strong association between purpose in life and conscientiousness is consistent with previous work of (Grant et al., 2009; Schmutte \& Ryff, 1997), and others have also documented the associations between this dimension and openness and neuroticism (Schmutte \& Ryff, 1997; Siegler \& Brummett, 2000). In line with these findings, this hypothesis was upheld. This shows that students who score high in Purpose in life items posses the characteristics of creating meaning and direction in life. It shows having goals in one's life and a sense of directedness which makes life more meaningful and gives it a purpose.

Hypothesis (1f) tested to find out if personality traits will influence psychological well-being (self-acceptance) among students in Schools of Nursing and Midwifery, Makurdi. The study accepted only openness on psychological well-being (self-acceptance) among students in Schools of Nursing and Midwifery, Makurdi. This work is consistent with the findings of Siegler and Brumment (2000) who found openness too positively predicted psychological well-being. Students who are high on self-acceptance display the tendencies of self evaluation that involves awareness and acceptance of both personal strengths and weaknesses. Self-acceptance items largely focus on self-esteem, positive comparison of self versus others, and elements of life satisfaction.

Hypotheses (2a, 2b, 2c, 2d, 2e, and 2f), which stated that, stress will negatively influence psychological well-being (autonomy, environmental mastery, personal growth, purpose in life, positive relations with others and self-acceptance) among students in Schools of Nursing and Midwifery, Makurdi. This finding rejected all the dimensions of psychological well-being that stress did not negatively predict psychological well-being among students in schools of nursing and midwifery, Makurdi but positively predicted their well-being. This means that students emotional and physical strain caused by their academic, clinical training and personal life activities did not have effect on feeling good and functioning effectively. These results could be explained by the fact that the students may have been exposed and adapted to their stress and such; it has no significant impact on their psychological well-being. This findings is in line with Boey, Chan, Ko, Goh, and Lin (2010) who found majority (35.4\%), of nurses in Singapore considered occupational stress as moderate, $32.4 \%$ considered it as high, and another $32.2 \%$ considered it as low. Role conflict has been found to have a positive relationship with psychological well-being. Also, Lepine, Lepine and Jacksun (2004) in his challenge-hindrance model stated that stressors can be positive or negative. Challenges are stressors that improve performance. Since the students are faced with positive challenges that will bring better outcome, this may be a reason why there overall psychological well-being was not affected.

In contrast, Chandraaiah, Agrawal, Marimuthu and Manoharan, (2003) found heavy workload lowers one's psychological well-being among individuals. 
Hypotheses (3a, 3b, 3c, 3d, 3e and 3f), postulated that, personality traits and stress will jointly influence psychological well-being (autonomy, environmental mastery, purpose in life, positive relations with others, personal growth, self- acceptance) among students in schools of nursing and midwifery, Makurdi. All the tested hypotheses revealed that personality traits and stress did not predict psychological well-being among students in Schools of Nursing and Midwifery, Makurdi. Therefore, those hypotheses were rejected. This could be possible among the students in Schools of Nursing and Midwifery, Makurdi owning to the fact that, at the entry point, the students are given orientation about the stressful and tedious nature of the profession. Hence, most of them might have prepared their minds to adapt and face the numerous tasks ahead. This view is supported by; Selye (1950) who explored the "fight or flight" reaction through the General Adaptation Syndrome (GAS). The GAS has three stages: alarm, resistance, and exhaustion. During the alarm phase, a person uses current resources to face the threat. In resistance, the person actively copes with the stressful event. In exhaustion phase, a person depletes the resources to cope with the stressor (Selye, 1956).

\section{Conclusion}

Despite the limitations of the present study, this study has expanded our knowledge in many ways. Therefore, we can conclude, based on the findings of the study that, Personality traits significantly predicted psychological well-being of students in Schools of Nursing and Midwifery, Makurdi. Particularly, conscientiousness, neuroticism and openness personality traits were found to influence psychological well-being while extraversion and agreeableness were the lowest personality traits influencing psychological well-being among students. In the contrary, stress rather positively predicted student's psychological well-being as against earlier postulation that stress will negatively and significantly influence psychological wellbeing among students.

It was also concluded, based on the findings, that personality traits and stress did not jointly influence psychological well-being among students in Schools of Nursing and Midwifery, Makurdi.

This finding of the study can help to design programs and strategies to boost students' psychological well-being knowing fully well their various personality traits. This will also help in their academic performance and clinical practice training.

\section{Recommendations}

Based on the findings, the following recommendations are put forward: authorities in Schools of Nursing and Midwifery, government and stakeholders should assist students through counseling to enhance their psychological well-being. Furthermore, School counselors and appropriate agencies should assist those students with extraversion and agreeableness traits to enhance their overall well-being. In addition, clinicians employed should assist to develop programs specifically aimed at assessing, diagnosing, treating, and possibly preventing problem areas for optimal psychological well-being among students. Further empirical research should be geared towards Student's Nurses/Midwives psychological well-being owning to their different personality traits in the course of their professional program. The Nigerian government should become more concerned with the 
personality traits and stress related issues affecting student's psychological well-being and implement policies that will promote their overall psychological well-being.

Also, psychological well-being is a multidimensional concept as proposesd by Carol Ryff, research should be focused on Ryff's dimensions of psychological well-being to assist students identify the dimensions that they are poor and improve on them since psychological well-being is not a single construct.

Further research should assess the difference in psychological well-being based on gender, socioeconomic, demographics, parent's level of education and age.

Moreso, stress, different personality and other psychological problems is known to have detrimental effects on the physical and mental well-being of students. Clinical psychologist's intervention is needed by assessing stress in students in schools of nursing and midwifery and determining its impact on psychological well-being in order to establish ways to decrease the risk and increase the positive level of psychological well-being.

Also, students who choose to go into nursing and midwifery profession should be prepared in advance for the stresses theory and clinical practice bring. This is concerning, having an awareness of the factors that contribute to positive and negative psychological well-being may give educators clues as to why some students excel under stressful conditions owning to different personality traits while others become overwhelmed.

Other research should examine whether those who score lower on psychological wellbeing make use of the services provided to them, and whether they rate their teachers any differently than those who score higher on psychological well-being. This could all be meaningful information in ensuring that the students have the best possible experience at schools of nursing and midwifery, Makurdi. Psychological stability is indeed an important predictor that could contribute to psychological well-being and enhance professionalism.

Researchers intending to carry out similar research should include more participants in the study to ensure representative sample size.

The replication of the current study in other States may be important in generalizing the results. 


\section{References}

Allport, G. (1961). Pattern and growth in personality. New York: Holt, Rinehart, \& Winston.

.Anglim, J., \& Grant, S. (2016). Incremental prediction Predicting psychological and subjective well-being from personality: from 30 facets over the Big 5. Journal of Happiness Studies, 17. http://dx.doi.org/10.1007/s10902-014-9583-7

American Psychological Association (2015). Publication Manual of the American Psychological Association (6 $6^{\text {th }}$ ed.). Washington DC: Author.

American Psychiatric Association. (2000). Diagnostic and Statistical Manual of Mental Disorders, Fourth Edition, Washington D.C.

Bakker, A. B., Schaufeli, W. B., Leiter, M. P., \&Taris, T. W. (2008). Work engagement: An Emerging Concept in Occupational Health Psychology.Work and Stress, 22, 187200. http://dx.doi.org/10.1080/02678370802393649.

Bandura, A. (1986). Social foundations of thought and action: A social cognitive theory. Englewood Cliffs, NJ: Prentice Hall.

Butler, J., \& Kern, M. L. (2016).The PERMA-Profiler: A brief multidimensional measure of flourishing. International Journal of Wellbeing,6, 1-48. http://dx.doi.org/10.5502/ijw.v6i3.1.

Bennett, J. B. (1988). Power and influence as distinct personality traits: Development and Theory, models and some new findings. Boulder, CO: Westview.

Berry, J. W. (1990). Psychology of acculturation. In J. J. Berman (Ed.), Nebraska Symposium on Motivation: Vol. 37, Cross - Cultural Perspectives University of Nebraska Press: Lincoln. Between physical activity and perceived stress/hassles in college students.

Boey, K-W., Chan, K-H., Goh, Y-C.\& Lin ,T-W, (2010). Stress, coping strategies and psychological well-being among nurses. Mahwah, NJ: Eribaum.

Boswell, W. R., Olson-Buchanan, J. B., \& LePine, M. A. (2004).Relations between stress and work outcomes: the role of felt challenge, job control, and psychological strain. Amsteram: Pergamon.

Bradburn; Norman, M. \& Noll S.C.E (1969).The structure of psychological well-being. Chicago: Aldine publication \& corporation.

Bray, \& Kwan, M. Y. W. (2006). Physical activity is associated with better health and psychological well-being during transition to university life. Journal of American College Health, 55(2), 77-82. doi: 10.3200/JACH.55.2.77-82 
Journal DOI: www.doi.org/10.46654/ij.24889849

Article DOI: www.doi.org/10.46654/ij.24889849.e7572

Bydawell, L. (2005). The impact of exercise on depression and psychological well-being. Retrieved from http://www.uzspace.uzulu.ac.za/handle/10530/333.

Chang, E. C. (1998). Does dispositional optimism moderate the relation between perceived stress and psychological well-being?: a preliminary investigation. Personality and Individual Differences, 25, 233-240.

Chang, E. C. (2006). Perfectionism and dimensions of psychological well-being in a college change. Psychological Medicine, 36, 1033-1042.

Chow, H. P. (2007). Psychological well-being and scholastic achievement among university students in a Canadian Prairie City. Social Psychology of Education, 10(4), 483-493.

Chandaraaiah K, Agrawal S. C., Marimuthu, P. and Manoharan N. (2003, May-August). Occupational stress and job satisfaction among managers.Indian Journal of Occupational and Environmental Medicine, 7(2), 6-11

Cohen, S., D. Janicki-Deverts, \& G.E. Miller (2007), Psychological stress and disease Journal of the American Medical Association, pp. 1684-1687

Cohen, S. (1996). Psychological stress, immunity, and upper respiratory infections. Current Directions in Psychological Science,5 (3), 86-90.

Cohen, S., Kamarck, T., \&Mermelstein, R. (1983).A global measure of perceived stress. combined/interactive effect of the Big Five traits. Personality and Individual. 17, 214223.

Compton, W. C. (1998). Measures of mental health and a five factor theory of personality. Conceptual foundations, empirical evidence, and directions for future research.28-67.

Cooper, C. L., Sloan, S. J., \& Williams, S. (1988). Occupational Stress Indicator.Journal of Psychology, 134, 490-502.

Costa, P. T., \&McCare, R. R. (1992).Revised NEO Personality Inventory (NEO PI-R) and NEO Five Factor Inventory (NEO-FFI) professional manual. Odessa, FL: Psychological assessment Resources. New York.

Costa, P. T., \& McCrae, R. R. (1980). Still stable after all these years: personality as a key to some issues in adulthood and old age. In P. B. Baltes \& O. G. Brim, (Eds.) Life span development and behaviour. (3rd. ed.) New York, NY: Academic Press.

Costa, P. T., \& McCrae, R. R. (1992). Revised NEO Personality Inventory and NEO FiveCouncil of International Organization for Medical Science (2000).Biomedical Research Ethics: Updating International Guidelines. Geneva: Author.

Costa, Jr., P. T. \&McCrae, R. R. (1992). NEO PI R Professional Manual, Florida: Psychological Assessment Resource Inc. 
Crystal, D. S., Chen, C., Fuligni, A. J., Stevenson, H. W., Hsu, C., Ko, H., Kitamura, S., \& Kimura, S. (2014).Psychological maladjustment and academic achievement: a crosscultural study of Japanese, Chinese, and American high school students. Child Development. 65 (3): $738-753$.

Creed, P. A., Machin, M. A., \& Hicks, R. (2009). Neuroticism and mental health outcomes for long-term unemployed youth attending occupational skills training programs. Personality and Individual Differences, 21(4), 537-544.

Danner, D. D., Snowdon, D. A., \& Friesen, W. V. (2001).Positive emotions in early life and DC: U.S Government Printing Office.

DeLongis, A., Folkman, S., \& Lazarus, R. S. (1988). The impact of daily stress on health and demands and worker health: Main effects and occupational differences. Washington, D.C.

DeNeve, K. M., \& Cooper, H. (1998). The happy personality: a meta-analysis of 137 depressive symptoms and self-esteem across a significant life transition. Journal of Psychology 42-45.

Diener E., Sapyta J. J., \&Suh, E. (1998). Subjective well-being is essential to well-being. Psychological Inquiry, 9, 33-37.

Diener, E., Oishi, S., \&Lucas,R. E. (2002). Subjective well-being: The science of happiness and life satisfaction. In C.R. Snyder \& S.J. Lopez (Ed.), Handbook of Positive Psychology. . p. 63 Oxford and New York : Oxford University Press.

DSM - 5 (2013). Diagnostic and statistical manual of mental disorders (5th ed). Washington, DC: APA.

Duckworth, A. L.; Steen T. A. \& Seligman M. E. P.(2005). Positive psychology in clinical practice, Annual review of clinical psychology, 1, 629-651.

Dyson, R., \&Renk, K. (2006). Freshman adaptation to university life: depressive symptoms, stress, and coping. Journal of Clinical Psychology, 62 (10), 1231-1244.

Edwards, S. (2002). Promoting mental health through physical exercise.UZ Journal of Psychology, 1(16), 18-22.

Edwards, S. (2003). Physical exercise and psychological wellness in health club members: a comparative and longitudinal study. South African Journal for Research in Sport, Physical Education and Recreation, 25(1), 23-33.

Edwards, S. (2006). Physical exercise and psychological well-being. Retrieved from http://sap.sagepub.com/content/36/2/357. 
Edwards, S., Edwards, D., \& Basson, C. (2004). Psychological well-being and physical selfesteem in sport and exercise. The international journal of mental health promotion, $6(1), 25$.

Edwards, S.D. (2004). Physical exercise and psychological well-being. International Journal of Mental Health Promotion, 4(2), 40-46.

Edwards, S.D., Ngcobo, H.S.B., \&Pillay, A.L. (2004).Psychological well-being in South African university students. Psychological Reports, 95, 1279-1282.

Edwards, S.D., Ngcobo, H.S.B., Edwards, D., \&Palavar, K. (2005). Exploring the relationship between physical activity, physical activity, psychological well-being and self-perception in different exercise groups. South African Journal for Research in Sport, Physical Education and Recreation, 27(1), 75-90.

Edwards, S.O. (2004). Mental health, physical activity and public health: A South African perspective. Paper presented at the Third World Congress of Mental Health Promotion in Auckland New Zealand.

Eisdorfer \& M. Lawton (Eds.). The psychology of adult development and aging (pp. 311335). Washington, D.C.: American Psychological Association.

Emmerson, C, P. (2009). Depression and its effects on young adults. Research paper unpublished. The Graduate School University of Wisconsin Stout: UWS. Emotional and cognitive evaluations of life. Annual Review of Psychology, 54, 403-encounter of two traditions. Journal of Personality and Social Psychology, 82, 1007- 1009.

Endler, N. S. (1997). Stress, anxiety, and coping: The multidimensional interaction model. Canadian Psychology, 38.

Endler, N. S., Edwards, J. M., \&Vitelli, R. (1991).Endler Multidimensional Anxiety Scales (EMAS): Manual. Los Angeles, CA.: Western Psychological Services. environmental research and public health, 8(5), 1308-1323.

Forsberg, C., \&Bjorvell, H. (I 993). Swedish population norms for the GHRI, HI and STAIstate. Quality of Life Research: An International Journal, 2 (5), 349-356.

Fox, K.R. (2000). Physical activity and mental health promotion: the natural partnership. International Journal of Mental Health Promotion. 2(1), 4-11.

Frasure-Smith, N., Lesperance, F., \&Talojic, M. (I995). The impact of negative emotions on prognosis following myocardial infarction: Is it more than depression? Health Psychology, 14 (5) 388-398. 
Journal DOI: www.doi.org/10.46654/ij.24889849

Article DOI: www.doi.org/10.46654/ij.24889849.e7572

Fayn, K., Tiliopoulos, N., \&MacCann, C. (2015). Interest in truth versus beauty: Intellect and openness reflect different pathways towards interest. Personality and IndividualDifferences, 81, 47-52. http://dx.doi.org/10.1016/j.paid.2014.12.031.

Garousifarshi, M. T., \&Soufiyani, H. (2008). Relationship Between Health and Personality of Student. Journal of Ferdosi University, 2, 47-63.

Garusifarshi, M. T. (2007). The relationships between dimension Big five personality and psycholological well-being among college students in Tabriz University Azarbaijan. Journal of Tabriz University, 4(7), 65-77. genetics of personality and well-being in a representative sample. Psychological Genetics, 31, 243-273.

Hagh-Shenas, H. (2010). The Study of personality traits relation psychological well being increase among adolescents on Shiraz College students. Medicienshiraz university, $6(3), 51-62$.

Hall, N. C., Chipperfield, J. G., Perry, R. P, Ruthig, J. C., \& Goetz, T. (2006). Primary And secondary control in academic development: gender-specific implications for stress and health in college students. Anxiety, Stress, and Coping, 19 (2), 189-210.

Hamarat, E., Thompson, D., Zabrucky, K. M., Steele, D., Matheny, K. B., \&Aysan, F. (2001). Perceived stress and coping resource availability as predictors of life satisfaction in young, middle-aged, and older adults.Experimental Aging Research, 27(2), 181-196. Happiness lead to success? Psychological Bulletin, 131, 803-855.

Hassmen, P., Koivula, N., \&Uutela, A. (2000). Physical exercise and psychological wellbeing: a population study in Finland. Preventive Medicine, 30(1), 17-25. doi:10.1006/pmed.1999.0597.

Haugland, S., Wold, B., \&Torsheim, T. (2003). Relieving the pressure? The role of physical activity in the relationship between school-related stress and adolescent health complaints.Research Quarterly for Exercise and Sport, 74(2), 127-135. doi:10.1080/02701367.2003.10609074.

Hayhoe, C. R., Leach, L. J., Turner, P. R., Bruin, M. J., \& Lawrence, F. C. (2000). Differences in spending habits and credit use of college students. The Journal of Consumer Affairs, 24 (1), 113133.

Headey, B., \& Wearing, A. (1989). Personality, life events, and subjective well-being: Health, 22(3), 179-188.

Howard D.A. (2011) Student nurses' experience of project 2000. Nursing Standard 15(48), 33-38. Implications for health and psychological well-being. Journal Of American College Health, 52(4), 181-188.

John, O. P., Donahue, E. M., \& Kentle, R. L. (1991).The Big Five Inventory--Versions 4a and 54. Berkeley, CA: University of California, Berkeley, Institute of Personality and Social Research. 
John, O. P., Naumann, L. P., \& Soto, C. J. (2008). Paradigm shift to the integrative Big Five trait taxonomy: History, measurement, and conceptual issues. In O. P. John, R. W. Robins, \& L. A. Pervin (Eds.), Handbook of personality: Theory and research (pp. 114-158). New York, NY: Guilford Press.

Joshanloo, M., \& Afshari, S. (2011). Big five personality traits and self-esteem as predictors of life satisfaction in Iranian Muslim University students. Journal of Happiness Studies, 12(1), 105-113.

Joshanloo, M., \& Rastegar, P. (2007). Investigation of the personality Predictors of eudaimonic well-being in male and female university students. Journal of Iranian Psychologists, 13, 13- 16.

Joseph, S. \& Wood, A. (2010). Assessment of positive functioning in clinical psychology: Theoretical and practical issues. Clinical Psychology Review, 30, 830-838. http://dx.doi.org/10.1016/j.cpr.2010.01.002.

Jones M.C. \& Johnston D.W. (2012) Distress, stress and coping in first-year student nurses. Journal of Advanced Nursing 26, 475-482.

Jones M.C. \& Johnston D.W. (2012).The derivation of a brief student nurse stress index. Work and Stress 13(2), 162-168.

Kahneman, D., Diener, E. \& Schwarz, N. (1991).Foundations of hedonic psychology: Scientific perspectives on enjoyment and suffering New York: Russell Sage Foundation.

Kahneman, D., Diener, E., \& Schwarz, N. (Eds.) (1999).Well-being: Foundations of hedonic psychology. New York: Russell Sage Foundation Press.

Kasl, S. V. \& Cobb, S. (1966). Health behavior, illness behavior and sick-role behavior. Archives of Environmental Health, 12, 246-266.

Kazemipoor, S. (2007). Residence experience and inclination to migrated to Tehran demography magazine, 2en year,No.3. 130-148.

Kean, T., Taylor, K., \&Penk, W. (1997). Differentiating post-traumatic stress disorder (PTSD) from major depression (MDD) and generalized anxiety disorders (GAD). Journal of AnxieLy Disorders, 11 (2) 317-328.

Kessler (Eds.), How healthy are we?: A national study of well-being at midlife. (pp. 398 422). Chicago: Univ. of Chicago Press.

Keyes, C. L. M. (2006). Mental health in adolescence: Is America's youth flourishing? American Journal of Orthopsychiatry, 76(3), 395-402. 
Keyes, C. L. M., Shmotkin, D., \&Ryff, C. D. (2002). Optimizing well-being: The empirical encounter of two traditions. Journal of Personality and Social Psychology, 82, 10071022. http://dx.doi.org/10.1037/0022-3514.82.6.1007.

Keyes, C. (2002). The mental health continuum: From languishing to flourishing in life. Journal of Health and Behaviour Research, 43, 207-222. http://dx.doi.org/10.2307/3090197.

Keyes, C. (2005). Mental illness and/or mental health? Investigating axioms of the complete state model of health. Journal of Consulting and Clinical Psychology, 73(3), 539548. http://dx.doi.org/10.1037/0022-006X.73.3.539

Keyes, C. (2009). The nature and importance of positive mental health in America's adolescents. In Gilman, R., Huebner, E., \& Furlong, M. (Eds.).Handbook of positive psychology in schools. New York: Routledge.

Keyes, C. L. M., Shmotkin, D., \& Ryff, C. D. (2002). Optimizing well-being: The empirical encounter of two traditions. Journal of Personality and Social Psychology, 82, 10071022. http://dx.doi.org/10.1037/0022-3514.82.6.1007

Kipping C.J. (2010). Stress in mental health nursing. International Journal of Nursing Studies $37,-218$.

Kjell, O. N., Nima, A. A., Sikström, S., Archer, T., \& Garcia, D. (2013). Iranian and Swedish adolescents: differences in personality traits and well-being. Peer J, 1, e197.

Larson, E. A. (2006) Stress in the lives of college women: "lots to do and not much time". Lawton. Experimental Aging Research, 9, 73-76.

Le Fevre, M., Kolt, G. S., \& Matheny, J. (2006). Eustress, distress and their interpretation in primary and secondary occupational stress management interventions: which way first? Journal of Managerial Psychology, 21 (6), 547-565.

Lenzi, A., et al. (I 993). Social class and mood disorders: Clinical features. Social Psychiatry and Psvchiatric Epidemiology, 28 (2) 56-59.

Librán, E. C. (2006). Personality dimensions and subjective well-being. The Spanish Journal of Psychology, 9(1), 38-44.

Lo R. (2012) A longitudinal study of perceived level of stress, coping and self-esteem of undergraduate nursing students: an Australian case study. Journal of Advanced Nursing 39(2), 119-126.

Lucas, R., Diener, E., \&Suh, E. (1996).Discriminant validity of well-being measures. Three decades of progress. Psychology Bulletin, 125, 276-301.

Magnus, K., Diener, E., Fujita, F., \&Payot, W. (1993). Extraversion and neuroticism as Management Guide. Windsor: NFER-Nelson. 
Marshall, L. L., Pharm, D., Allison, A., Nykamp, D., Lanke, S. (2008). Perceived stress and quality of life among doctor of pharmacy students. American Journal of Pharmaceutical Education, 72(6), 137-144.

Manshor, A. T., Fontaine, R. and Chong, S. C. (2003). Occupational stress among managers: A Malaysian survey.Journal of Managerial Psychology, 18, 622-628. DOI: 10.1108/02683940310494412.

McConnell, G. N., \& Jenkins, J. M. (2001). Suicide and depression among college students: a decade later. Professional Psychology: Research and Practice, 32 (1), 97-100.

McCrae, R. R. (1983). Extraversion is not a filter, neuroticism is not an outcome: a reply to the full five-factor model.

McEwen, B.S., \&Sapolsky, R. M. (1995).Stress and cognitive function. Current Opinion in Neurobiology, 5, 205-216.

McNulty, K., Livneh, H., \& Wilson, L. M. (2004). Perceived Uncertainty, Spiritual WellBeing, and Psychosocial Adaptation in Individuals With Multiple Sclerosis. Rehabilitation Psychology, 49(2), 91. Meanings. Journal of Personality and Social Psychology, 73, 549-559.

Mehdizadeh, N., \& Scott, G. (2005). Adjustment problems of Iranian international students in Scotland. International Education Journal,, 6(4), 484-493.

Menezes, R.G. (2007). Psychological morbidity, sources of stress and coping strategies among undergraduate medical students of Nepal. BMC Medical Educational, 7, 2633.

Misra, R., \& Castillo, L. (2004). Academic stress among college students: comparison of American and international students. International Journal of Stress Management, 11 (2), 132-148.

Misra, R., \& McKean, M. (2000) College students' academic stress and its relation to their anxiety, time management, and leisure satisfaction. American Journal of Health Studies, 16.

Mahat G. (2010) Stress and coping: junior baccalaureate nursing students in clinical settings. Nursing Forum 33(1), 11-19.

Misra, R., \& McKean, M. (2000). College students' academic stress and its relation to their mood: Psychological and social resources. Journal of Personality and Social Psychology.

Motevaliyan, S., M. (2014). Personality traits and severity of wife abuse among Iranian women. Handbook of personality. New York: Guilford Press. 
Murff, S. H. (2005). The impact of stress on academic success in college students. (pp. 213229). New York: Sage. Academic stress and academic performance.Educational Psychology, 23(3), 287 294. Achievement. Journal of Applied Psychology, 72, 522528. adaptation theory of well-being.

Neugarten, B. L. (1973). Personality change in middle life: a developmental perspective. The psychology of adult development and aging (pp. 311-335). Washington, DC: American Psychological Association. Neuroticism (and trait anxiety, self-mastery, and self-esteem): a re-evaluation of the New York: Cambridge University Press.

Neugarten, B. (1968). The awareness of middle age. In B. Neugarten (Ed.), Middle age and aging (pp. 93-98). Chicago: University of Chicago Press.

Nonis, S. A., Hudson, G. I., Logan, L. B., \& Ford, C. W. (1998).Influence of perceived control over time on college student's stress and stress-related outcomes. Research in Higher Education, 39 (5), 587-605.

Nwana O.C (1996). Introduction to educational research for student's teacher. Ibadan Heinemann Education books ltd. Journal of personality and social psychology, 51(6), 1257. on hedonic and eudaimonic well-being. Annual Review of Psychology, 52, 141-166.

Oppenheimer, B. T. (1984). Short-term small group intervention for college freshmen. Journal of Counseling Psychology, 31(1), 45-53.

Özen, Ö. (2012). ErgenlerinÖznelI_yiOlus_ Düzeyleri.Yüksek Lisans Tezi, Hacettepe Üniversitesi Sosyal Bilimler Enstitüsü, Ankara. Perceived stress. Journal of Health and Social Behavior, 24 (4), 385-396). Predictors of objective life events: A longitudinal analysis. Journal of Personality.

Probst, M. (2003). Changes in psychological well-being in female patients with clinically diagnosed depression: an exploratory approach in a therapeutic setting. Psychology health and medicine, 8(4), 399. Process. Journal of Personality and Social Psychology, 69, 890-902.

Pruessner, J. C., Hellhammer, D. H., \& Kirschbaum, C. (1999). Burnout, perceived stress, and cortisol responses to awakening. Psychosomatic Medicine, 61, 197-204. Psychological Reports, 83, 371-381.

Raynor, D. A., \& Levine, H. (2009). Associations between the five-factor model of personality regression based approach. New York: The Guilford Press.

Reibel, D. K., Greeson, J. M., Brainard, G. C. \&Rosenzweig, S. (2001). Mindfulness-based stress Reduction and health-related quality of life in a heterogeneous patient population. General Hospital Psychiatry, 23, 183-192. Relationship between intention and physical activity: A moderated mediation analysis. Relationship: the role of the Big Five. Journal of Occupational Health Psychology, 12, Research Psychologists Press. 
Journal DOI: www.doi.org/10.46654/ij.24889849

Article DOI: www.doi.org/10.46654/ij.24889849.e7572

Robert-McComb, J. (2001). Eating disorders in women and children, prevention, stress, and treatment. Florida: Boca Raton.

Ryff, \& Keyes, C. L. (1995). The Structure of Psychological Well-Being Revisited J Pers Soc Psychol 69(4), 719-727.

Ryff, C. (1989). Happiness is everything, or is it? Explorations on the meaning of psychological well-being. Journal of Personality and Social Psychology, 57, 10691081.

Ryff, C. D., \& Keyes, C. L. M. (1995). The structure of psychological well-being revisited. Journal of Personality \& Social Psychology, 69(4), 719-727.

Ryff, C. (1989). Happiness is everything, or is it? Explorations on the meaning of psychological well-being. Journal of Personality and Social Psychology. 57(6), 10691081.

Ryan, R.M., \& Deci, E.L. (2001). Happiness and human potentials: A review of research on hedonic and eudaimonic well being. Annual Review of Psychology, 52, 141-166.

Ryff, C. (1989). Scales of psychological well being. Journal of Personality and Social Psychology, 57, 1069-1081.

Ryff, C. (1991): The structure of psychological well being. Journal of Personality and Social Psychology, 69, 719-727

Ryff, C. D., \& Keyes, C. L. M. (1995). The structure of psychological well-being revisited. Journal of Personality and Social Psychology, 69, 719-727.

Ryff, C. D., \& Singer, B. H. (2006).Best news yet on the six-factor model of well-being. In Snyder, C.R., Lopez, S.J. (Eds.), Handbook of Positive Psychology 541-555: Oxford: University Press.

Ryff, C. D., Keyes, C. L. M., \& Hughes, D. L. (2004). Psychological well-being in MIDUS: Profiles of ethnic/racial diversity and life-course uniformity.In O. G. Brim, C. D. Ryff\& R. C.

Ryff, C., \& Singer, B. (2005).Integrative science in pursuit of Human Health and Well-being. In Snyder, C.R., Lopez, S.J. (Eds.), Handbook of Positive Psychology 541-555: Oxford: University Press.

Rogers, C. (1961). On becoming a person. Boston: Houghton Mifflin. Ridner, S. L., Newton,

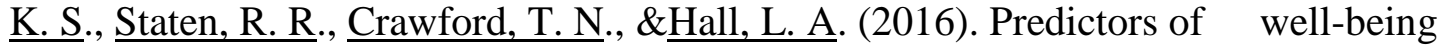
among college students. Journal of America College Health. 64(2):116-24. doi: 10.1080/07448481.2015.1085057. 
Ryff, C. (1989). Happiness is everything, or is it? Explorations on the meaning of psychological well-being. Journal of Personality and Social Psychology, 57, 10691081.

Ryff, C., \& Keyes, C. (1995). The structure of psychological well-being revisited. Journal of Personality and Social Psychology, 69, 719-727.

Safdar, S., Lewis, J. R., \& Daneshpour, M. (2006). Social axioms in Iran and Canada: Intercultural contact, coping and adjustment. Asian Journal of Social Psychology, 9(2), 123-131.

Saraceno, B., \& Saxena, S. (2002). Prevention and promotion in mental health.Lancet, 362, 574. Satisfaction: a critical examination. Psychological Bulletin, 130, 574-600. Scale. Journal of Personality Assessment, 49, 71-75.

Schmutte, P. S., \&Ryff, C. D. (1997). Personality and well-being: what is the connection? Journal of Personality and Social Psychology. 73, 549-559.

Schwarzer, R. (I 990). Current trends in anxiety research.In P. J. D. Drenth, J. A. Sergeant, \& R. J. Takens (Eds.), European Perspectives in Psychology. Vol. 2. (pp. 225-244.) Chichester, UK: John Wiley \& Sons.

Seligman, M. E. P. (2011). Flourish: A visionary new understanding of happiness and wellbeing. New York: Free Press.

Schwarzer, R. (I 996). Thought control of action: Interfering self-doubts.In 1. G. Sarason, G. R. Pierce, \& B. R. Sarason (Eds.), Cognitive interference: Theories, methods, and findings (pp. 99-115). Mahwah, NJ: Erlbaum.

Schwarzer, R., \& Renner, B. (2000). Social-cognitive predictors of health behavior: action self-efficacy and coping self-efficacy, Health-Psychology, 19, 487- 495.

Schwarzer, R., \&Schröder, K. (1997). Effects of self-efficacy and social support on postsurgical recovery of heart patients. Irish Journal of Psychology, 18 (1), 88103.Science, 19, 205-210.Science, 7, 186-189. science, 99-104.Science.

Scully, D. (1998). Physical exercise and psychological well-being: a critical review. British Association of Sport and Medicine, 32, 111-120.

Schwartz, G. E., \& Bonner, G. (1998). Effects of mindfulness- based stress reduction on medical and premedical students. Journal of Behavioral Medicine, 21 (6), 581-599.

Selye, H. (1956). The stress of life.Selye, H. (1974). Stress sans détresse: Lippincott.

Shah M, Hasan S, Malik S, Sreeramareddy C T (2010) Perceived stress, sources and severity of stress among medical undergraduates in a Pakistani Medical School. doi:10.1186/1472-6920-10 2. 
Shek D T L (2003) Meaning in life and psychological well-being: an empirical study using the Chinese version of the Purpose in Life Questionnaire.The Journal of Genetic Psychology.153(2), 185-200, doi 10.1007/s11205-004-8035-x Wong P T P (1998) Meaning-centered counseling.In P.

Sloan, R. P. \&Bagiella, E. (2002).Claims about religious involvement and health outcomes. Annuals of Behavioral Medicine, 24 (1), 14-21. Sreeramareddy, C. T., Shankar, P.T., Binu, V.S., Mukhopadhyay, C., Ray, B.

Smith, R. E. (1989). Effects of coping skills training on generalized self-efficacy and locus of control. Journal of Personality and Social Psychology 56(2), 28-33.

Smillie, L. D., Varsavsky, V., Avery, R. E., \& Perry, R. (2016). Trait intellect predicts cognitive engagement: Evidence from a resource allocation perspective. European Journal of Personality, 30, 215-226.http://dx.doi.org/10.1002/per.2059.

Snijders, T. A. B., \& Bosker, R. J. (1999). Multilevel analysis: An introduction to basic and Social Psychology, 54, 486-495. Social Psychology, 61(5), 841-846.Social Psychology, 65, 1046-1053. Social Science Research, 35, 1103-1119.

Spielberger, C. D. (1983). Manual for the State-Trait Anxiety Inventory (STAI).PaloAlto, CA: Consulting Psychologists Press.

Spring (2005).The Ryff Scales of Psychological Well-Being.University of Iowa.

Waterman, A.S. (1993). Two conceptions of Happiness: Contrasts of personal expressiveness (Eudaimonia) and Hedonic Enjoyment. Journal of Personality and Social Psychology, 64 (4), 678-691. W H O (1993). International statistical classification of diseases. status, and psychological symptoms. Journal of Personality and Social Psychology, 50(3), status, and psychological symptoms.Journal of Personality and Social Psychology, 50(3).

M. Argyle, \& N. Schwarz (Eds.), Subjective Well-being: an interdisciplinary perspective. Oxford: Oxford University Press,pp.27-48.

Singer, M. et al, (1986). "Report of the APA task force on deceptive and indirect techniques of persuasion and control (DIMPAC report)" American Psychological Association.

Strauser, D. R., Lustig, D. C., \& Ciftci, A. (2008). Psychological well-being: its relation to Stress Management, 21(2), 162. Strivings in the Type A pattern: Differential effects on students' health and academic student sample: a test of a stress-mediation model. Journal of Social and Clinical students in a Canadian Prairie City.

Suedfeld, P. (1997). Reactions to societal trauma: distress and/or eustress. Political Psychology, 18(4), 849-861. Support, and health problems in college students. Applied Developmental Science, 2(3). 
Steel, P., Schmidt, J., \& Shultz, J. (2008). Refining the relationship between personality and subjective well-being. Psychological Bulletin, 134, 138-161. http://dx.doi.org/10.1037/0033-2909.134.1.138.

T. P. Wong \& P. Fry (Eds.), The handbook of personal meaning: Theory, research, and practice (pp. 395-435). Mahwah, NJ: Lawrence Erlbaum Associates.

Taliaferro, L. A., Rienzo, B. A., Pigg, M., Miller, D., \& Dodd, V. (2008). Associations between physical activity and reduced rates of hopelessness, depression, and suicidal behavior among college students. Journal of American College Health, 57 (4), 427 435. the challenge-hindrance and sociocognitive models of stress.

Thoits, P. A. (1995). Stress, coping, and social support processes: Handbook of basic stress. New York: Guilford Press.

Tice, D. M., \& Baumeister, R. F. (1997). Longitudinal study of procrastination, stress, and health: the costs and benefits of dawdling. Psychological Science, 8 (6), 454-458.

Torres, J. B., \& Solberg, V. S. (2001). Role of self-efficacy, stress, social integration, and family support in latino college student persistence and health. Journal of Vocational Behavior, 59, 53-63.

Toward a dynamic equilibrium model. Journal of Personality and Social Psychology, validation of a psychometric measure. Journal of Research in Personality, 22, 361365.

Van Eck, M. Berkhof, H., Nicolson, N., \&Sulon, J. (1996). The effects of perceived stress, traits, mood states, and stressful daily events on salivary cortisol. Psychosomatic Medicine, 58, 447-458.

Vredenburg, K., O’Brien, E., \&Krames, L. (1988). Depression in college students: personality and experimental factors. Journal of Counseling Psychology, 35 (4), 419425.

Weiss, A., Bates, T. C., \& Luciano, M. (2008). Happiness is a personality thing: the well and being yourself. Journal of Personality and Social Psychology, 74, 494-512. wellbeing of students from seven universities in the UK. International journal of well-being.

Westefeld, J. S., \&Furr, S. R. (1987).Suicide and depression among college students. Professional Psychology: Research and Practice, 18 (2), 119-123. 5 work personality, vocational identity, and career thoughts. Journal of Psychology.

Zajacova, A., Lynch, S. M., \& Espenshade, T. J. (2005).Self-efficacy, stress, and academic. Science, 50, 70-73.

Zeidner, M. (1988).Health and demographic correlates of trait anxiety in Israeli adults. Anxiety Research, 1:(2) 127-135. 